\title{
The Ordeal of a Petrostate Amidst Declining Oil Revenue and Implications on Budgetary Objectives: An ARDL Bound Test Approach for Angola
}

\author{
Millicent Adanne Eze ${ }^{1 *}$ \\ School of Business, Law and Social Sciences, Abertay University Scotland, United Kingdom \\ * E-mail of the corresponding author: ezemillicent@gmail.com \\ ORCID: https://orcid.org/0000-0002-2951-4027
}

\begin{abstract}
The combination of the quest for renewable energy for global decarbonisation and the decrease in economic activities across the world due to the COVID-19 pandemic has brought about the incessant plunge in the oil prices leading to a sharp decline in oil revenues of most of the oil-exporting countries. Hence, deterioration in trade, a decrease in economic growth, and inability to meet the nation's fiscal needs. This study analyses declining oil revenue implications on the budgetary objectives of the oil-exporting countries - the case of a petrostate, Angola, which is the second-largest oil exporter in sub-Sahara Africa. The Autoregressive Distributed Lag (ARDL) Bound Test Approach is used to estimate the model's parameters. Yearly time series data for 39 years (1981-2019) were employed for the empirical analyses. The unit root tests were first carried out using the Augmented Dickey-Fuller (ADF) and Philips Peron's (PP) Tests. The Unit Root results indicate that all the variables are stationary at level $\mathrm{I}(0)$ and at first difference I(1). This outcome was the basis for the choice of the ARDL estimation technique for the analyses. Primary data were also used to supplement the secondary data analysis. The results show that Angola's government revenue decreased significantly as oil price declines, which indicate that Angola is overwhelmingly relying on oil exports for its sustainability. Contrary to expectation, the results reveal that a percentage decline in oil price exerts a positive and substantial impact on the Angolan economy's government expenditures, financed mainly through borrowing and seigniorage. It is highly recommended that Angola diversifies their revenue base, develop other mineral resources in the economy aside oil and ensure effective management of government funds. However, an economic model is proposed to close the revenue gap in this highly oil-dependent nation.
\end{abstract}

Keywords: Petrostate, ARDL Bound Test Model, Declining Oil Revenue, Ordeal, Oil Price

DOI: $10.7176 / \mathrm{JESD} / 12-10-04$

Publication date:May $31^{\text {st }} 2021$

\subsection{Introduction}

Most petrostates, especially those having oil as their "heart-beats", face multiple economic crises in recent times; mainly from the COVID-19 pandemic, which has crippled the global economic activities and from the collapse of the global oil price, which shrinks the oil revenue of most of the oil exporters. The carbon reduction target also drives the present crisis in the global oil market. Significant improvement in technology to gradually shift from hydrocarbon-based economies to the ones based of a more sustainable form of energy, thereby making renewable energies to be the most preferred energy option due to the low cost of its production and being less hazardous to the environment (Lahn and Bradley, 2020; Elgouacemi et al., 2020). Over the years, fluctuating oil prices have been a constant phenomenon. The consequences and the causes of changes in oil price have been an issue of concern among different academics, researchers and policymakers alike. Although the impact of this continuous fluctuation differs across nations, and this depends on whether the economy is oil-importing or oil-exporting. Oil price is very critical to both oil-importing and oil-exporting nations in dealing with the affairs of the economies as it serves as a good source of revenue generation to oil-exporting nations and as a crucial input to oil importers. Both are highly dependent on oil politically and economically; as such, the fluctuations in oil price adversely affects both market sides.

However, April 2020 was the very first time in history where the West Texas Intermediate moved towards negative while the Brent Crude price declined significantly as most of the oil-exporting countries are tremendously susceptible to constant volatility in the oil market. The volatility in the global oil price did not begin today but started even before the 70s while future trading supports the increasing speculation in the oil market. Both high demand and high oil supply contributed to the high fluctuations that are frequently seen in the global oil market.

\footnotetext{
${ }^{1}$ Many thanks to all the participants at the Annual Conference of the 2019 Scottish Economic Society (SES), for their candid suggestions and comments. Thanks also to all the participants at the Abertay Graduate School Conference in 2019, for the insightful comments. I am also very thankful to my sponsor: Tertiary Education Trust Fund (TETFUND) for the funding support of my research degree (PhD) and for this research project. Kindly address all the correspondence to: Dr Millicent Adanne Eze, School of Business, Law and Social Sciences, Abertay University, Dundee, Scotland-United Kingdom; E-mail: ezemillicent@gmail.com
} 
More so, the current decline in the demand for oil was further exacerbated by the unanticipated COVID-19 pandemic that led to the decline in production and mobility of oil across the globe due to the quarantines and the lockdowns in almost all the countries of the world, thereby leading to the drastic decline in the demand for oil which became lower than never before in history. Hence, it produced a ripple effect of a crash in the financial markets and the drastic decline in the oil revenue of most of the oil-exporting countries; particularly, the Angolan economy. However, the drastic contraction of global oil demand in recent times is the first after the global financial crisis of 2009. On the supply side, the inability of the Organization of the Petroleum Exporting Countries (OPEC) to cut production as proposed during their meeting on the $5^{\text {th }}$ of March, 2020, aggravated the plunge in oil price to $\$ 31.1$ per barrel (WTI) on the $9^{\text {th }}$ of March 2020. It further declined to $\$ 11.57$ per barrel (WTI) by the $21^{\text {st }}$ of April 2020 due to the impact of the COVID-19 pandemic (OECD, 2020; Taghizadeh-Hesary 2020).

The impact of these established factors on oil-exporting economies differs across nations as some countries have the capability of "weathering the storm" than others due to their excess savings in terms of the Sovereign Wealth Fund. The Angolan economy as a petrostate is the second oil exporter and the third largest economy in sub-Sahara Africa. Crude oil accounts for more than 90 percent of its export earnings, half of its Gross Domestic Products and over 80 percent of Angola's tax revenues (Brock, 2015). Consistently, Mohammed, (2018) reveals that the Angola's oil sector accounted for over 97 percent of the nation's total exports and more than 54 percent of Angola's gross domestic product between 2006 and 2015. However, the Angolan economy is having the challenges of high level of public debt, deterioration in terms of trade, decline in tax revenue, high level of insecurity and unable to attract foreign investments, hence, low level of economic growth and development. The economic activities in Angola were projected to slow down as other sectors adjust to the reduction in the private consumption and public sector investments. Nevertheless, the economy grew rapidly after the end of the civil war, which lasted from 1975 to 2002 but the recent sharp decline in the price of oil has exhausted the dollar influxes, smashed the local currency, hammered public finances and stimulated heavy government borrowing (Mohammed, 2018; Energy Information Administration, 2017; Brock, 2015; Engebretsen, R. 2015).

However, the purpose of this study therefore, is to examine the impact of declining oil revenue on the budgetary objectives of the Angolan economy, amidst the unanticipated COVID-19 pandemic that has ravaged the entire globe. The Angolan government could not Cater for the poor and the welfare of its citizens during periods of increasing oil revenue; as such, the major concern is how Angola would be able to meet with the nation's fiscal needs in this new paradigm shift to oil revenue, necessitated by the depressed crude oil price.

\subsection{Literature Review}

Empirically, increasing oil price leads to deterioration in macroeconomic variables, while price decrease has a relatively small expansionary effect on macroeconomic variables (Balli et al., 2016). Although this impact is dependent on whether the economy is oil-importing or oil-exporting as the changes in these variables are highly unpredictable thereby affecting both oil importers and oil exporters differently (Aliyan, 2013). However, the link between oil price fluctuation and economic activity have been carried out using various econometric techniques. Some of these researchers include Nzimande and Msomis (2016); Baumeister and Kilian (2016); TaghizadehHesari and Yoshino (2015); Kaplan (2015); Yoshino and Taghizadeh-Hesari (2014); Shi and Sun (2012), Oladosu, (2009), Gounder and Bartleet (2007), Canada and de Gracia, (2005), Hamilton, (2009, 2005,1983). Most of these authors arrived at similar conclusion that high oil price affects economic activity negatively while decreasing oil price have a positive impact on businesses. On the contrary, some other studies established an asymmetric relationship between oil price and economic activity. The discovery indicates that increasing oil price has a significant impact on the business while decreasing oil price have a less substantial positive impact on activities of the economy affected (Lardic and Mignon, 2008; Zhang, 2008; Brown and Yucel, 2002; Mory, 1993; and Mork 1989). On the other hand, Hooker (1996) found no relationship between oil price and the macroeconomic variables. There is, therefore, the need for the justification of these discrepancies among researchers regarding the impact of the macroeconomy and oil price fluctuations relationship.

Balli et al. (2016) examined the impact of oil price fluctuations on the macroeconomic variables in Turkey and found that there is a bi-directional causal relationship between GDP and inflation. There is also a causal relationship running from oil price to the gross domestic product and inflation. Also, Taghizadeh-Hesari and Yoshino (2015); Yoshino and Taghizadeh-Hesari (2014) assessed the impact of oil price changes on two macroeconomic variables: the gross domestic product (GDP) growth rate and the inflation rate \{consumer price index $(\mathrm{CPI})\}$. These factors, when considered in three highest oil-consuming economies: United States, of America, Japan, and China, reveal that the interests on the impacts of oil prices and the macroeconomy are highly topical due to the drastic increase in oil price from 2001 and the corresponding decline that followed immediately after the global financial crisis of 2008 - 2009. Using the N-variable Structural Vector Autoregression (SVAR) model, the result reveals that the impact of the fluctuations in oil price on the gross domestic product (GDP) of developed oil-importing economies (The USA and Japan) is highly insignificant when compared with those of emerging economy (China). Similarly, the impact of oil price fluctuation on the emerging economy's inflation 
rate was lower when compared with those of the developed countries. However, the economies under consideration are mainly developed and oil-importing economies. More so, the study considered only the periods of increasing oil price.

Consistent with the above argument, Blanchard and Gali (2007) on examining the macroeconomic effects of an oil price shock on the US economy using SVAR concluded that the consequences of oil price fluctuations on inflation and economic activity were large. The oil price could only explain some parts of the 1970s oil price changes. The study concludes that the effects of changes in oil price on the inflation rate and activity are significant; while the US economy imported more than $50 \%$ of the nation's oil and gas consumption (Hooker, 1999) which has likely classified the economy as an oil-consuming economy as portrayed by Taghizadeh-Hesari and Yoshino (2015). Aydin and Acar (2011) examined Turkey as an oil-importing economy, and the result shows that there are significant effects of increasing oil prices on macro indicators and about $5 \%$ rise in inflation. They also reveal that the increasing oil price makes it very hard for economies with large oil import financial plan to be able to settle their budget shortfalls.

Farzanegan, and Markwardt, (2009) also carried out an analysis of the dynamic relationship existing between oil price movements and key macroeconomic variables in Iran using the VAR model. In the study, it is evident that there is a positive correlation between fluctuations in oil price and industrial output growth. However, the focus was mainly on the real oil shock from 1975 to 2006, and the outcome is logical since Iran is an oil-exporting economy whose oil revenue increases because of the increase in oil price. Hence, there is the possibility of growth in output. In line with the above, Hesary et al. (2013) estimated the impact of oil price shocks on oil-exporting economies (Iran, Russia, and Canada) and their trade partners. The outcome shows that the direct and indirect effects of a positive oil shock on the gross domestic products of Iran and Russia are positive while the direct effect is negative for Canada due to the small impact that the oil export contributes to their gross domestic product. The indirect effect on Canada is positive because of their high involvement in the exportation of final products.

Monaldi (2015) examined the impact of declining oil prices on Venezuela's macroeconomy. The study shows the existence of a 3-digit inflation rate, a fall in the gross domestic product, current account deficit, contraction in production and a very high political instability. However, the robustness of the outcome is highly questionable since there is no statistical evidence shown. More so, the economy is likely to experience serious macroeconomic instability due to the decline in oil revenue but the magnitude of the effects, not ascertained because no statistical tool or technique was employed. However, graphical representation, as shown in the study, is not sufficient in the explanations of the impact of declining oil price fluctuations on the macroeconomy. Bruno and Sachs (1986) first gave a detailed analysis of the effects of oil price fluctuation on inflation and output for most developed economies in the 70s. The study mainly explored the role of monetary policy as well as the role of other shocks. Bruno and Sachs (1986) argue that most oil price increases of the 1970s and the corresponding oil demand decrease in response to the force of inflation led to the decay of most of the economies during the period. On the other hand, Hamilton, (1983) asserts that increases in oil price have been responsible for most of the major recessions in the U.S.A and that post-OPEC macroeconomic performance determines increases in oil price. However, the extent of the effect of the changes in oil price was not specified.

On the contrary, Shi and Sun (2012) examined the relationship between oil price movements and the macro economy in both China and India and found that there is no significant causality between most of the macroeconomic variables and oil price fluctuations. The study further stressed that the inflation rate, increases initially and then remain positive while the gross domestic product moves positively in both economies. Consistent with the above position, Hooker, (1999) in assessing whether the oil price shock is inflationary discovered that within the 1980s, the movements in oil price slightly affected inflation while its effects before the 1980s on inflation were highly significant. The study also reveals that the relationship between inflation and oil price movements would produce a spurious result by the linear, constant-coefficient specifications inherent in most Philip's curves. In other words, the non-linear specification is likely to give a better and reliable outcome. However, all the above studies centred on the effect of increasing oil price on the macroeconomy.

Hooker (1999) maintained that the relationship between oil and the macroeconomic variables might be difficult to identify because of the behavioural nature of the time series data on the oil price. Secondly, the systematic way that monetary policy responds to oil price fluctuations, makes it tough for the macroeconomic effects to be recognised (Hoover and Perez, 1994; Romer and Romer, 1989). More so, due to the lack of dominant theoretical tool as most researchers previously argued that changes in oil price affect the macroeconomy diversely depending on the applied analytical instrument. These effects could be through the terms of trade as an import price (Hesary et al., 2013) or the production function as an input price or as a relative price movement, which leads to inter-sectorial reorganisation. Consistently, Darby (1982) found no relationship between oil price and macroeconomic variables. Farzanegan and Markwardt, (2009) in using a VAR framework for the Iranian economy, analysed the dynamic relationship between oil price fluctuations and macroeconomic variables. The results indicate that both positive and negative oil price shock increases inflation while a positive correlation exists between increasing oil price and output growth. Also, Mork, 1989 opined that what matters most is the increase 
in oil price rather than decreasing oil price effect on an economy. Hamilton, (1996) argues that oil price increase only matters when they are large enough about the previous experience. Nzimande and Msomis (2016) on examining oil price changes and economic activity in South Africa suggests through the findings that both positive and negative oil price shocks are important as they both have asymmetric impacts on economic activities.

Consequently, Bohi (1991) argued that the oil price does not have any substantial macroeconomic effects by themselves. Aliyan, (2013), on the other hand, posits that changes in oil price have effects on the revenue base of most oil-exporting economies, which in turn affects the macroeconomic variables. Tatom (1987) carried out a theoretical analysis of oil price effects on the macroeconomy and concluded that oil price increases or decreases have symmetric consequences for the economy. However, no analysis was carried out as evidence was based on previous assumptions surrounding analysis of oil price increases and decreases. There was no inclusion of macroeconomic variables as no statistical was carried out. Also, the Granger causality tests between oil price changes, the gross domestic product (output) and unemployment deteriorate when the series of data extends beyond the 1980s (Hooker 1996; Lee et al. 1995 and Mork 1989). The above affirms the views of Hamilton, (1996), Lee et al. (1995) and several other researchers who argued that the high inconsistency inherent in the results of oil price fluctuations after the 1985 periods portray elements of misspecification. As such, there is a need to run oil price changes through the application of the nonlinear models to be able to capture the macroeconomic effects.

Conversely, some recent studies have a contrary opinion to the above conclusions. For instance, Al-Quadsi and Ali (2016) portrayed that the fluctuations in oil price have both the long and short-term effects on the macroeconomy. Lorusso and Peironi (2015) in examining the causes and consequences of oil price fluctuations in the United Kingdom reveal that the real oil price and domestic inflation have positive correlation while growth in the gross domestic product falls with the fall in oil supply. Ogundipe et al. (2014) assert that oil price changes have a significant effect on the exchange rate volatility in Nigeria. In addition, Oriakhi and Iyoha (2013) reviewed the effect of an oil price shock on Nigeria's economic growth. They concluded that there exists a relationship between oil price changes and macroeconomic variables. As such, the Nigerian economy is very susceptible to oil price fluctuations, which has made it difficult for the attainment of the expected growth target. On the contrary, Arewa and Nwakahma, (2013) examination of this relationship in Nigeria reveals that the variables do not Granger 1 cause each other.

Furthermore, in Ayadi (2005) study for Nigeria, regarding the relationship between oil price fluctuations and macroeconomic variables; the result reveals an insignificant relationship. Consistently, Iwayemi and Fowowe (2011) reveal that oil price fluctuation has no significant impact on the main macroeconomic variables. Relatively, Olomola and Adejumo, (2006) study for Nigeria also suggests a substantial impact of oil price fluctuations on macroeconomic variables, thereby confirming the Dutch disease syndrome in Nigeria. Also, Eltony and Al-Awadi (2001) examined this impact in Kuwait and found that there is a high degree of the interrelationship among major macroeconomic variables. Similarly, Mehrara, (2008) in examining this relationship in 13 oil-exporting economies found that the relationship between the GDP and oil revenues are asymmetric and non-linear while the magnitude of the positive oil shock is less than that of the negative price shock. However, the case under consideration is mainly that of increasing oil price. The impact of decreasing oil price on the macroeconomic variables is rare and scanty. Using an SVAR framework, Taghizadey-Hesary and Yoshino, (2015) examined the impact of oil price fluctuations on the growth rate of GDP and inflation in the United States, China and Japan. The results reveal that the implications of the fluctuations in the oil price of an emerging economy's GDP growth are higher in comparison to developed oil importers GDP growth. On the other hand, the impact of oil price fluctuations on the inflation rate of the two developed economies (The USA and Japan) is higher when compared with the Chinese economy. Consistently, Hamilton (2005) examined oil and the macroeconomy variables of the United States and concluded that one of the macroeconomic effects of oil price fluctuations is in the inflation rate. In other words, there exist a relationship between oil price and the macroeconomic variables. Although, majority of these studies deal with the case of increasing oil price while most of the economies under consideration are developed and oil-importing countries especially the USA in which most related studies on the impact of oil price fluctuations on the macroeconomic variables are focused. For instance, the studies of Blanchard and Gali, 2010; Bollino, (2007); Jones et al., (2004); Balke et al (2002) and, Bruno and Sachs, (1986). Similarly, other authors explored the relationship between fluctuations in oil prices and macroeconomic variables in developing oilimporting economies such as Turkey - (Balli et al., 2016; Aydin and Acar, 2011; Ozlale and Pekkurnaz 2010); Morocco - Jbir and Zouari-Ghorbel (2009); Pakistan - Malik (2010); Tunisia - Jbir and Zouari-Ghorbel (2009).

However, other studies centres on the impact of increasing oil price on the macroeconomic variables of oilexporting economies. Some of these studies include Nigeria-(Stober, 2016; Imarhiagbe, 2015; Ademola et al., 2015; Ogundipe et al., 2014); Angola - Engebretsen, (2015). Although, Mohammed, (2018) carried out a more

1 The lagged values of the time series variables granger cause each other when the values of one of the variables provide statistical information about the future value of the other variable. 
closely related study for Angola but the study differs significantly from this research as it focused only on the examination of the relationship between oil production and growth in Angola. From all the literature reviewed, it shows that studies on the impact of decreasing oil price on the macroeconomic variables of developing and oilexporting countries have received less attention especially for a petrostate like the Angolan economy. However, to the best of my knowledge, there is no such related studies for the Angolan economy. Given the diverse views and the divergent conclusions of most researchers as to the impact of oil price fluctuations on the macroeconomic variables, it gave rise to the derivation of the research hypotheses of the study. The null hypotheses $\left(\mathrm{H}_{0}\right) \mathrm{s}$ which states that there is no impact of declining oil price on the government revenues (GREV); government expenditures (GEXP); economic growth (GDP); external reserves (EXTR); inflation rates (INFR) and the unemployment (UEMR) rates of the Angolan economy; were tested as against the alternative hypotheses $\left(\mathrm{H}_{1}\right) \mathrm{s}$. However, the interconnections between the research Objectives, examinable hypotheses and the theories are as shown below:

Figure 2.1 Interconnections between the Research Objectives, Examinable Hypotheses and the Theories



Source: Author's design

\subsection{Research Methodology and Methods}

The choice of an appropriate research methodology plays significant roles in any research. It helps to ensure the accuracy and validity of the data. It also aids in the prevention of spurious results from the analyses to be carried out (Collis and Hussey 2014; 2009). Nevertheless, the research process depends mainly on the research philosophy and the research paradigm, which the researcher adopts for the study.

\subsection{Research Philosophy and Paradigm}

The Research philosophy entails the coordination of beliefs surrounding the study under consideration. It encompasses the nature of knowledge, existence and reality, thereby elucidating the process involved in gathering 
the required data, the analysis and its applicability to the real world (Waite and Hawker, 2009; Galliers, 1991). Research philosophy can also be referred to as the assumptions surrounding how the researcher views the real world, as the assumptions will underpin the research strategy and methods used in the research process, which is vital in any study (Saunders et al., 2012). It thereby shows the research evidence, sources of data and its interpretation to address the research questions. The research philosophy enables the researcher to identify the research design that would enable the researcher to achieve the research objectives and to determine the limitations associated with each of the research approaches. Research philosophy also helps researchers to identify or create new research design.

On the other hand, research paradigm is an essential aspect of any research, which serves as the philosophical structure that guides the researcher on the best way to conduct the research. It is also perceived as a framework, comprising researcher's beliefs, assumptions and philosophies about the world, the nature of reality and the sources of knowledge (Collis and Hussey, 2014; 2009; Easterby-Smith et al., 2012; Saunders et al., 2012; Gliner, Morgan, and Leech 2009; Bryman, 2008).

Collis and Hussey $(2014 ; 2009)$ and Benton and Craib, (2001) maintain that there are two main research paradigms: Positivism and interpretivism. Positivism originated from natural science, based on the principle of realism. It relies on the assumption that social reality is objective, singular and is indifferent to the act of investigating it, which therefore means that the act of investigating social reality has no impact on that reality. The positivist research involves a deductive process, which centres on theories for the explanation and understanding of social phenomena. The positivist believes that the researcher is independent of the phenomena under study. More so, the positivist paradigm relates to the quantitative methods of analysing research data as it assumes that social phenomena are quantifiable (Creswell, 2014; Collis and Hussey, 2014; Saunders et al., 2012; Corbin and Strauss, 2008).

On the contrary, interpretivism as a paradigm emerged due to the criticisms of the positivist paradigm to meet the needs of the social world. The interpretivists believe that social reality is subjective, multiple, perceived in our minds and not possible to separate the researcher from that research itself or from what exists in the social world. Hence, the researcher interacts with the phenomena under study. It is based on the principle of idealism. Just as the positivist believe in the measurement of a social phenomenon, the interpretivist believes in the exploration of the complexity of social phenomena through interpretive understanding. For the interpretivist, research findings emerge through qualitative methods of analysis, which is based on the interpretation of qualitative research data (Collis and Hussey, 2014; Creswell, 2014). One of the main criticisms of the positivist paradigm is the fact that capturing complex situations in the social world in a single measure is ambiguous and has not recognised the Participants feelings by separating people from the study they are investigating. The interpretivism paradigm is criticised for uncritical acceptance of the reports from the participants and the relevance of human subjectivity in the research (Collis and Hussey, 2014; Easterby-Smith et al. 2012). However, this research relies on ontological objectivism and epistemological positivism as the main research philosophy underpinning the study. Ontological assumption deals with the nature and structure of reality which raises question about how the world functions while epistemological assumption relates with the origin and value of knowledge.

Figure 3. 1: Research Philosophy and paradigm underpinning this Study

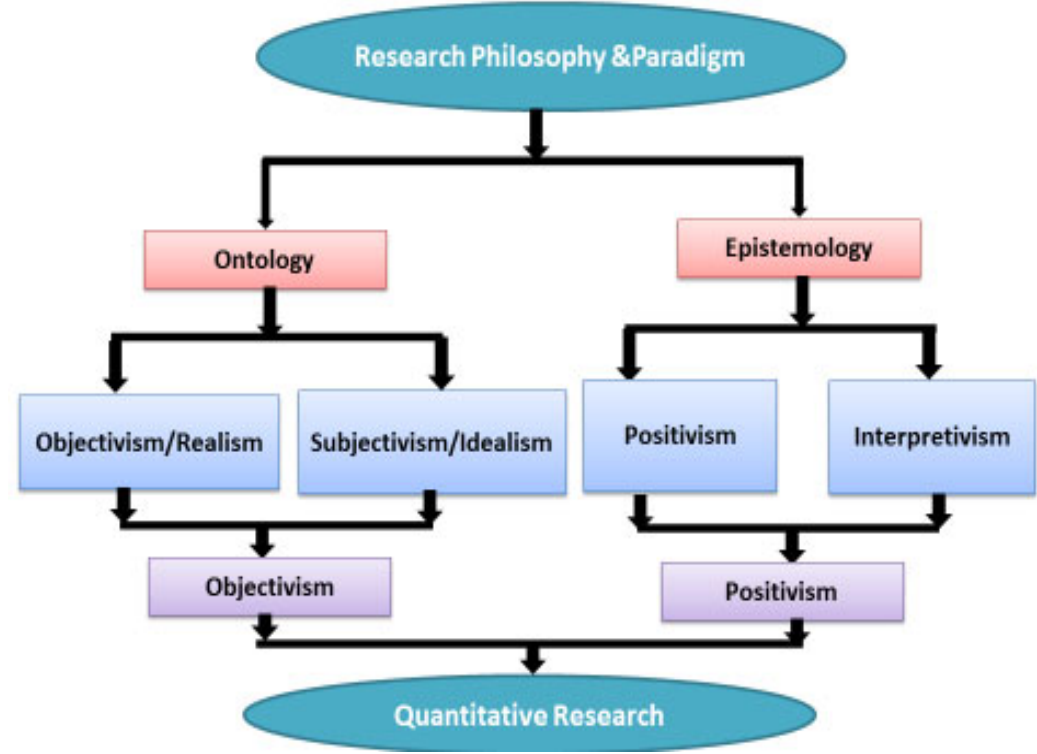

Source: Author's design

The choice of ontological objectivism and epistemological positivism as the philosophy underpinning this 
research is because the hypotheses derived from the literature are mainly quantitative and were analysed quantitatively as well. More so, the variables involved are numerical while the time series data are collected are from 1981 to 2019. Although, we can relate it to the types of mixed methods design as outlined in Morse and Niehaus, (2009), whereby the core component of the research is quantitative (QUAN) with a qualitative (qual) supplementary component and vice versa. This study proves to be mainly quantitative (QUAN) in nature with supplementary qualitative (qual) data which were sourced from the questionnaires and then quantified and analysed quantitatively.

\subsection{The Choice of Positivism}

This study embraced the positivist paradigm due to the following reasons: First, positivism assumes that the methods used in the natural sciences, which are quantitative, are applicable to the social science phenomena (Collis and Hussey, 2014). The use of large samples is also imminent in positivist research like this study, which was carried out using statistical analysis from 1981 to 2019 (39 years) for the Angolan economy.

Secondly, positivism is concerned with the testing of research hypotheses (Collis and Hussey, 2014, 2009). There are examinable hypotheses, which emanated because of the divergent views from the literature about the effects of oil price fluctuations on macroeconomic variables, which were tested as it involves quantitative data set while the analyses were carried out in an artificial location, an econometric laboratory to be precise. Hence, the adoption of a more objective stance towards the study is essential (Saunders et al., 2012).

Thirdly, the positivist paradigm provides a highly structured methodology using statistical analysis based on quantitative research data. More so, precise, objective and quantitative data are some of the concerns of the positivist's paradigm (Collis and Hussey, 2014). Statistical analyses were carried out, but the choice of the time series models adopted depends mainly on the outcome of the diagnostic tests. The qualitative data, which were sourced through the primary means (questionnaires), were quantified to supplements the secondary data results.

\subsection{Research Approach}

It is vital to adopt an appropriate research approach to support the research philosophy, and research paradigm which underpins any study (Saunders et al., 2012). Bryman (2016) opine that two main research approaches prevail, which includes the deductive and inductive approaches. The deductive approach entails deriving the conclusions from a set of premises, which are the hypotheses and theories that emerge from the literature by the researcher (Saunders et al., 2012). Consistent with the above, Coolican, (2014) maintain that a deductive approach involves the development and testing of research hypotheses based on existing theory while Collis and Hussey, $(2014,2009)$ describe the deductive approach as moving from the general to specific. It is associated with the positivist paradigm and mainly, with quantitative research (Collis and Hussey, 2014, 2009; Bryman and Bell, 2007). Following a deductive approach in any investigation means that the research would involve the formulation of relevant research hypotheses, which would be tested through the application of the relevant research methodology Gulati, (2009). Conversely, the inductive approach is the reverse of the deductive approach, which entails moving from specific observations to broad general patterns and theories. It emphasises the development of theory from data collection and presentation of results through the statistical analysis of from the observation of empirical reality. The inductive research approach also entails deducing general inferences from specific instances. It is associated with the interpretivist paradigm, involving qualitative research (Bryman and Bell, (2015); Collis and Hussey, 2014, 2009). Saunders et al., (2012) maintain that this approach deals with moving from the specific to the general while the observations and relevant research theories are formulated at the end of the research.

However, this study adopts the deductive approach. Through the relevant related literature reviewed, research hypotheses were formulated as regards to the impact of oil price fluctuations on macroeconomic variables and the null hypotheses were tested as against the alternative hypotheses through the application of the appropriate research methodology.

\subsection{Sources of data}

The main variables of the models in this study are time series of macroeconomic variables. These variables include: Government Revenue (GREV), Government Expenditures (GEXP), Oil Price (OILP), Gross Domestic Product (GDP), External Reserves (EXTR), Inflation Rates (INFR), Exchange Rates (EXCR) and Unemployment Rates (UEMR). The two exogenous variables in the model are EXCR and OILP while the main independent variable is Oil price. Although the exchange rate is also an independent variable but serves more as a control variable in the model. The data were sourced from the World Bank, International Energy Agency, National Statistics Office (Instituto Nacional De Estatisticas Angola), Trading Economics (2019). However, Nkoro and Uko, (2016) reveal that most time series variables are usually non-stationary and can generate serious problems while estimating the relationships between economic variables. Unit roots are the main source of non-stationarity and using time series data which has unit toots for any regression analyses would produce spurious regression and misleading outcomes. However, the unit root properties of the macroeconomic variables adopted in this study were tested before carrying 
out the analyses. The Autoregressive Distributed Lag (ARDL) Bound Test Approach was employed to estimate the parameters of the model using yearly time series data for 39 years (1981-2019). Pesaran et al. (2001), outlined several strengths that the ARDL estimation technique has over the traditional Engel-Granger and Johansen approach. This method helps prevent the endogeneity problem and is used to produce both the long-run and the short-run estimates of the model simultaneously. Also, Marques et al., (2016) and Pesaran et al., (2001) believe that the ARDL bounds methods are not affected when dummy variables are involved in any model. The variables of the model could also have different lag lengths when using the ARDL technique, while this is not obtainable when analysing using the conventional Johansen method of cointegration. However, the unit root tests were first carried out using the Augmented Dickey-Fuller (ADF) and Philips Peron's (PP) Tests. The Unit Root results indicate that all the variables are stationary at level $\mathrm{I}(0)$ and at first difference $\mathrm{I}(1)$. This outcome was the basis for the choice of the ARDL estimation technique for the analyses. The unit root result is attached in the appendix A.

The primary data were sourced using questionnaires aimed at supplementing the results of the secondary data analysis. The questionnaires contain a total of ten questions, comprising of eight closed-ended questions and two open-ended questions while five-point Likert scale order (Strongly Disagree, Disagree, Neutral, Agree and Strongly Agree; ranging from 1 to 5; while stands for strongly disagree and 5 represents strongly agree) was used for the design of the questionnaires because it is considered to be highly acceptable and reliable. It is also used so frequently in most survey analysis and considered to be of excellent standard (Mellor and Morore, 2014; Likert, 1932). However, Survey Monkey platform, an online cloud-based tool was used for the administration and collection of the questionnaires. The Survey Monkey online platform helps researchers to lunch any kind of survey; tailor the surveys to any specified target audience and enables researchers to reach out to millions of respondents while obtaining real-time results.

\subsection{Theoretical Framework}

The theoretical framework of any research provides the rationale for conducting any investigation as it helps to reveal the underlying assumptions relating to ones' research. The assumptions, however, are established in theory (Simon and Goes, 2013; Trochim, 2006). The theoretical framework also serves as the lens which aids the researcher in justifying the foundation and the scope of the study, whether inductive or deductive (Ocholla and Le Roux, 2011; Zielder, 2007). Swanson and Chermack (2013) view the theoretical framework as the structure, which backs the research theory as it, explains the reasons behind the existence of the research problem. From the preceding, theory is to research what the "heart" is to the body and as such can be referred to as the nucleus of any investigation as it controls the growth of the cell and gives signals to the body. In like manner, theories controls, coordinates, and shows clearly the direction of any research and reasons for its existence.

Based on existing literature, there are quite some valuable theoretical perspectives surrounding the increasing and declining effects of oil revenues on the budgets of both oils importing and oil-exporting economies. The conventional theories of oil price are the main tenets of theories identified in the literature of oil revenue effects on the budgets of both oil-exporting and consuming nations (Hayes, 2015; Gosling, 2016; Al-Zeaud, 2015; Mupimpila et al 2015; Olaoye, 2014; Aladejare, 2014; Al-Qahtani et al., 2008; Reddick, 2003 and 2004; Al-Yousef, 1998; Sielke, 1995; Wilson and Sylvia, 1993; Linderoth, 1992; Downs and Rocke, 1984; Padgett, 1980). Principally, the research assessed three major theories upon which this research is based. These are the revenuespend and spend-revenue hypotheses; theories of budgetary decision making of oil revenue decline and the economic growth theories.

\subsubsection{Revenue-Spend and Spend Revenue Hypotheses}

Revenue-Spend hypothesis originates from Friedman (1978), and it entails a unidirectional causality running from revenue to expenditures. It, therefore, means that an increase in government revenue would lead to an increase in government expenditure, which would lead to the inability of reducing the budget deficit gaps. Although Buchanan and Wagner (1978) contend that an increase in government revenue is the best remedy for budget deficits. Since the revenue-spend hypothesis is evidenced in this study, budget deficits can be avoided by implementing policies that would help in stimulating government revenue.

Spend-Revenue hypothesis, on the other hand, was proposed by Peacock and Wiseman (1979), and it is built on the tenet that expenditures cause revenues. That is, when government expenditures increase due to political and economic crises, government revenues increase as well. This means that the government spends first and then raise revenues to pay for the expenditures later. The spend-revenue hypothesis, therefore, suggests that decreasing government expenditures can reduce budget deficits.

\subsubsection{The Theories of Budgetary Decision Making of Oil Revenue Decline}

The theories of budgetary decision-making are part of the internal change theories, which examine the budget procedure changes within the government of any nation. External influences outside the immediate control of the government do not have any significant impact on budgetary decisions. The internal change theories primarily examine the changes, ability and the size of variations in the fiscal choice of a given nation from one period to the next. 
There are three main theories within the class of internal change budgetary theories such as rational expectations theory; The Incrementalism, otherwise known as the Bureaucratic Process theory and The Garbage Can Theory. The rational expectations theory has been used traditionally in the explanations of the macroeconomic behaviour as the governments face inter-temporal budgetary constraint, which entails the budget-balancing, in the long-run. It requires enough time for the budget to adjust either through revenue increase or decrease in expenditures. The current decisions of the government would have a significant impact on the options that would be available in the future. The US, United Kingdom and Canadal follow the logic of this theory (Reddick, 2004; 2003; Downs and Rocke, 1984).

The rational expectations theory was introduced by; Hamilton and Flavin (1986) who wants to find out if the government is subject to a constraint in the public finance literature. This theory assumes that decision-makers have all the necessary information at their disposal and should be able to make policy choices to determine the budget of the economy concerned. The budget makers are assumed to think and act rationally about the future, consider all the possible outcomes of the budgeting processes and not just using the previous decisions to determine the government's current budget. They choose the best solution through unanimous agreement. It is a forwardlooking process that all the available information are for future planning (Reddick, 2004; 2003; Downs and Rocke, 1984).

The rational expectations theory has some limitations, as it requires more information and more time. It also assumes that the criteria for the decision-making are rational, measurable and readily available. The theory assumes perfect knowledge of all the alternatives, preferences, non-political world, goals and consequences.

This theory centres on the future in making a budgetary decision while the decision-makers are assumed to have the time and the needed resources to take the right decision in the budgetary process. Indeed, even as the revenues of most oil-dependent nations are on the decline due to the recent fall in oil price. As such, creating time and looking into the future of these economies by the decision-makers would enable the right decisions to be taken in the budgetary process.

Oil serves as the mainstay of the oil-dependent nations and as such, generating more revenues to carry out the statutory roles of these nations require the best budgetary policy to revitalise the nations. Oil dependent nations require adequate information to come out with a sound budgetary outcome for the economy. Since the main study purpose is to find out the economic consequences of decline oil revenue in consideration of long-term position, this validates the adoption of rational expectations theory as one of the theories upon which the research is based. Budgetary incrementalism theory is also known as the bureaucratic theory of decision making (Sielke, 1995; Cibulka, 1987; Downs and Roche, 1984; Wildavsky, 1964). This theory is a rival model of decision making in the internal change framework. The theory states that the spending decisions made in the past determine the current spending decisions (Reddick, 2004, 2003; Berry, 1990). The Incremental theory was first identified by Lindblom (1987) and is recognised globally as a dominant descriptive budgetary theory for almost three decades now. It centres on events from the discovery of the problem to the possible solution (Khan, 2002; Khan and Hildreth, 2002; Wildavsky, 1964). The agencies can select the incremental funding with an equal percentage increase across the different programmes. For instance, incrementalism applies whenever an agency requests for a proportionate increase in funding its various budgetary programmes. Budgets are driven by historical data since the budget incrementalism represents slight changes from the budgetary base. An important characteristic of this theory is the avoidance of a comprehensive investigation of the budgetary needs. It is, therefore called 'a theory of avoidance' (Jordan, 2002). Khan and Hildreth (2002) and Sharkansky, (1969) argue that incrementalism theory gives room for budget outcomes to be separated from controversy since controversies may still be inherent within policy makers.

Conceptually, incrementalism is known as the amount of steadiness in the design of the budgetary outputs over time. In-so-far-as the underlying incremental patterns of budgetary outputs are specified, the assessment of the incremental nature of the budget could be through the evaluation of the adherence of its budgetary output to the pattern over time (Ibrahim and Proctor, 1992). Most of the empirical studies on incrementalism centred mainly on the federal and state levels, (Reddick, 2003, 2004; Caiden, 1994; Ibrabim and Proctor, 1992; Thompson, 1987; Downs and Rocke, 1984; Lowery et al. 1984; Padgett, 1980; Davis et al., 1966). At the local level, incrementalism has been universal as a descriptive theory (Jordan, 2002; Khan and Hildreth, 2002). The theory is concerned with change at the margin as decision-makers usually lack the information that could facilitate existing expenditures and the need for future spending. Regarding, this theory, only slight changes are made to existing budgetary programmes as the budget mainly comprises of a repetition of the previous budget and the standard operating procedure of adding a marginal increase to the past year's budget (Ibrahim and Proctor, 1992; Wildavsky, 1964). Incremental theorists argue that decision making in the society is highly complex at all times and as such, requires the development of a short cut to facilitate the decision-making process (Lindblom, 1958,1959).

1 The US, United Kingdom and Canada aligned their budgets with the Rational Expectation theory. See, Reddick (2004a; 2004b); Downs and Rocke (1984). 
Three incremental strategies include previous years' increment approach in which the agencies demand the same percentage increase across the programmes as was appropriated in preceding years. Secondly, inflation strategy whereby, the agency administrators to determine the incremental use the inflation funding index funding. Thirdly, the best guess strategy whereby the agency officials use their wealth of knowledge through budgetary experience to form the best guess about the increment to request for in the budget procedure (Whicker and Mo, 2002; Caiden, 1994). However, whenever an economy has a favourable environment, the incremental budget strategies are most likely to be used. Incrementalism had severe shortcomings, as it could not clearly show the relationship between the outcome and the behaviour. It did not show clearly whether the outcome was incremental because the behaviour was incremental. Secondly, defining incremental as the outcome is in itself ambiguous (Reddick 2004a, 2004b; Whicker and Mo, 2002; Caiden, 1994; Berry, 1990).

From the preceding, the budgetary decision-making theory underpins this study, particularly the rational expectations theory and the incrementalism theory. The inflation rate strategy and the best guess strategy perfectly fits into this study, but the previous year's incrementalism theory has no base in this research. As the revenue of the government declines due to the decrease in oil prices, increasing the budget of each of the programmes by equal proportion as the 'previous year's budget' suggests, would not be possible due to the shortfall in the government's oil revenues. If the income of the current budget is higher than the previous, then it would be justifiable for decision-makers to increase the budgets by the same proportion as the previous year's budget or even more. The main issue of concern is the revenue shortfall, which needed to be improved to enable these oildependent nations, especially the petrostate - Angola to be able to meet with their budgetary requirements.

3.5.3 Economic Growth Theories

Economic growth theory entails the increase in the goods and services produced by a nation measured as the real gross domestic product percentage adjusted for inflation (Weils, 2016). Antwi et al. 2013 posit that economic growth is an increase in real gross domestic product, adjusted for inflation. Endogenous growth theories are present in the works of Cesaratto, (2008) and Solo, (1970). The main types of economic growth theories underpinning this study are the exogenous and endogenous growth theories. The classical theory of economic growth emerged during the eighteenth and nineteenth centuries through the works of Adam Smith, David Ricardo and Robert Malthus, which states that every nation has a steady-state GDP and any deviation from the GDP is temporary, as it would eventually return to its original state. It relies on a simple concept that population grows with the growth in GDP and tends to grow more due to the rising demand higher than the available resources which will eventually cause the GDP to return to its steady-state (Weil, 2016; Idrisov et al. 2015). Population indeed grows with the growth in GDP, but deviations in GDP are inevitable and may not be temporary as well as not return to its steady state. For instance, the fluctuations in the oil price which has a ripple effect on the GDP through the oil revenue of oil-exporting nations have lingered for a while now and has a further effect on another aspect of the economy. The theory, therefore, does not fit into this study as economic growth is attainable through savings in oil revenue while substantial investment of oil revenue leads to high growth in GDP (Adesola et al., 2014; Barkhordara and Sboohi 2013; Hamdi and Sbia, 2013; Pettinger, 2015). Hence, the classical theory of economic growth does not underpin this study because both increasing and decreasing in the gross domestic product of the nation may be correlated with the population growth but is unlikely to return to its steady-state as outlined in theory due to the unpredictable nature of activities in the global oil market.

Two economists, Robert Solow and T.W. Swan developed the Solow-Swan growth model. They emphasised that labour, capital and technology are factors that impact growth in an economy. Therefore, the exogenous growth theory state that output per worker increases with output per capital but at a decreasing rate known as diminishing marginal returns. Hence, the increase continues to a point where capital and labour attain an equilibrium state. The theory entails that economic growth is unattainable except through advancement in technology, which happens by chance. Labour and capital adjust immediately with technological advancement while there will be an equal level of the living standard once all the economies have access to same technology (Sinha, 2015; Barkhordar and Saboohi, 2013; Mehrara 2011; Todaro \& Smith 2004).

The conclusions that economic growth can only be attainable with the advancement in technology and happens by chance is ambiguous, while it is not possible, for all the nations in the world to have access to same technology to have an equal living standard. It is indeed a theory of growth, but this aspect of the theory does not fit into this study (Weil, 2016). The Solow-Swan growth model, also known as exogenous growth theory, assumes that external factors are primarily responsible for economic growth and not through internal factors. Solow's model maintains that economic growth is unattainable in the absence of technological process.

Conversely, the endogenous growth theory is an economic theory, which contends that economic growth originates from inside a system as a direct outcome of internal processes. That is, economic growth is an endogenous outcome of an internal economic structure (Sinha, 2015; Parker, 2012; Pettinger, 2015; Romer, 1994; 1990). It entails that human capital enhancement will lead to economic growth through the development of new forms of technology and effective means of production. They also posit that there is a need for the government of a nation to support technological innovation (Sinha, 2015; Cesaratto, 2008; Pettinger, 2015; Grossman and 
Helpman, 1994). The endogenous growth theory has a connection to the budgetary decision-making theories where the actions and reactions of the decision-makers (human capital) determine the fiscal performance of the economy. More so, for the exogenous growth theory, technological progress would be achieved through the external sector, which involves the interaction in the exportation of the economies resources and other means of generating revenues for the nation in the long run.

For an endogenous growth model, with the help of human capital and technological innovation, economic growth can be achieved. This assertion is entirely in line with this study as both the endogenous and exogenous growth theories underpin the study because the oil-exporting countries would be able to achieve the desired growth from both within the system and externally through the external sector performance. Hence, this study relies on both the endogenous and exogenous growth theories. Different studies such as (Kryeziu, 2016; Ali et al., 2015; Antwi et al., 2013; Iqbal and Zahid, 1998; Suliman and Osman, 1994; Grossman and Helpman, 1994) have shown that economic growth relates to macroeconomic variables. Although economic growth is, a complex macroeconomic phenomenon given the fact that it is still difficult to distinguish which of the determinant that has greater or less impact on growth (Kryeziu, 2016). Also, Antwi et al. (2013) found a co-integration relationship between economic growth and macroeconomic variables in Ghana. In Pakistan, high inflation rate, increasing foreign debt, low level of physical and human capital is mainly the source of unstable economic growth inherent in the economy. More so, macroeconomic stability in any nation leads to economic growth as every nation aspires for a sustainable economic growth, which measures the entire economic development of a country and brings about good standard of living in an economy (Ali et al., 2015; Suliman and Osman, 1994).

\subsection{Model Specification and Estimation Technique}

The unit root results for Angola have mixed results, with the series, stationary at both level "I(0)" and at first difference, "I(1)". The stationarity of the variables at different orders (i.e. I(0) and I(1)) but not I(2) supports the use of the ARDL estimation technique. Eviews 10 statistical package was employed, which automatically determine the lag lengths using the Schwarz Information Criteria (SIC).

However, the Autoregressive Distributed Lag (ARDL) estimation technique is employed for the analysis based on the outcome of the unit root tests, due to its numerous advantages. Pesaran et al., (2001), Nayaran and Smyth (2005) outlined several strengths, which the ARDL bounds test cointegration and ECM method have over the traditional Engel-Granger and Johansen approach. The method helps to prevent the endogeneity problem and also can produce both the long-run and the short-run estimates of the model concurrently. Also, Marques et al., (2016),), and Pesaran et al., (2001) maintain that the ARDL bounds methods are not affected when dummy variables are included in the model. More so, the variables of the model could have different lag lengths when using the ARDL technique, but this is not obtainable when using the conventional Johansen method of cointegration for analysis. It is also assumed that the sample size of the variables is relatively small for it to produce viable results.

\subsection{Estimation of the Underlying ARDL Model}

The Autoregressive Distributed Lag model for each of the variables to be estimated are as specified below:

$$
\begin{aligned}
& \Delta \ln G R E V_{t}=\alpha_{0}+\sum_{i=1}^{p} \alpha_{1} \Delta \ln G R E V_{t-i}+\sum_{i=0}^{q} \alpha_{2} \Delta \ln G E X P_{t-i}+\sum_{i=0}^{r} \alpha_{3} \Delta \ln O I L P_{t-i}+\sum_{i=0}^{s} \alpha_{4} \Delta \ln G D P_{t-i} \\
& +\sum_{i=0}^{u} \alpha_{5} \Delta \ln E X T R_{t-i}+\sum_{i=0}^{v} \alpha_{6} \Delta \ln I N F R_{t-i}+\sum_{i=0}^{w} \alpha_{7} \Delta \ln U E M R_{t-i}+\sum_{i=0}^{z} \alpha_{8} \Delta \ln E X C R_{t-i} \\
& +\lambda_{1} \ln G R E V_{t-1}+\lambda_{2} \ln G E X P_{t-1}+\lambda_{3} \ln O I L P_{t-1}+\lambda_{4} \ln G D P_{t-1}+\lambda_{5} \ln E X T R_{t-1} \\
& +\lambda_{6} \operatorname{lnINFR_{t-1}}+\lambda_{7} \operatorname{lnUEMR_{t-1}}+\lambda_{8} \ln E X C R_{t-1}+\lambda_{9} \text { Dummy }
\end{aligned}
$$

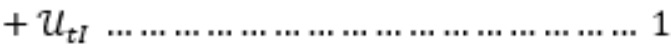




$$
\begin{aligned}
& \Delta \ln G E X P_{t}=\beta_{0}+\sum_{i=1}^{p} \beta_{1} \Delta \ln G E X P_{t-i}+\sum_{i=0}^{q} \beta_{2} \Delta \ln G R E V_{t-i}+\sum_{i=0}^{r} \beta_{3} \Delta \ln O I L P_{t-i}+\sum_{i=0}^{s} \beta_{4} \Delta \ln G D P_{t-i} \\
& +\sum_{i=0}^{u} \beta_{5} \Delta \ln E X T R_{t-i}+\sum_{i=0}^{v} \beta_{6} \Delta \operatorname{lnINFR_{t-i}}+\sum_{i=0}^{w} \beta_{7} \Delta \ln U E M R_{t-i}+\sum_{i=0}^{z} \beta_{8} \Delta \ln E X C R_{t-i} \\
& +\lambda_{1} \operatorname{lnGREV}_{t-1}+\lambda_{2} \operatorname{lnGEXP_{t-1}}+\lambda_{3} \operatorname{lnOILP}_{t-1}+\lambda_{4} \operatorname{lnGDP}_{t-1}+\lambda_{5} \ln E X T R_{t-1} \\
& +\lambda_{6} \operatorname{lnINFR}_{t-1}+\lambda_{7} \operatorname{lnUEMR}_{t-1}+\lambda_{8} \operatorname{lnEXCR}_{t-1}+\lambda_{9} \text { Dummy } \\
& +u_{t I I} \\
& . .2 \\
& \Delta \ln G D P_{t}=\gamma_{0} \sum_{i=1}^{p} \gamma_{1} \Delta \ln G D P_{t-i}+\sum_{i=0}^{q} \gamma_{2} \Delta \ln G R E V_{t-i}+\sum_{i=0}^{r} \gamma_{3} \Delta \ln O I L P_{t-i} \sum_{i=0}^{s} \gamma_{4} \Delta \ln G E X P_{t-i} \\
& +\sum_{i=0}^{u} \gamma_{5} \Delta \ln E X T R_{t-i}+\sum_{i=0}^{v} \gamma_{6} \Delta \ln I N F R_{t-i}+\sum_{i=0}^{w} \gamma_{7} \Delta \ln U E M R_{t-i}+\sum_{i=0}^{z} \gamma_{8} \Delta \ln E X C R_{t-i} \\
& +\lambda_{1} \operatorname{lnGREV}_{t-1}+\lambda_{2} \operatorname{lnGEXP}_{t-1}+\lambda_{3} \operatorname{lnOILP}_{t-1}+\lambda_{4} \operatorname{lnGDP_{t-1}}+\lambda_{5} \operatorname{lnEXTR}_{t-1} \\
& +\lambda_{6} \operatorname{lnINFR}_{t-1}+\lambda_{7} \ln U E M R_{t-1}+\lambda_{8} \operatorname{lnEXCR}_{t-1}+\lambda_{9} \text { Dummy } \\
& +u_{t I I I} \\
& \text {... } 3 \\
& \Delta \operatorname{lnEXTR}_{t}=\theta_{0} \sum_{i=1}^{p} \theta_{1} \Delta \ln \operatorname{EXTR}_{t-i}+\sum_{i=0}^{q} \theta_{2} \Delta \ln G R E V_{t-i}+\sum_{i=0}^{r} \theta_{3} \Delta \operatorname{lnOILP_{t-i}} \sum_{i=0}^{s} \theta_{4} \Delta \ln G E X P_{t-i} \\
& +\sum_{i=0}^{u} \theta_{5} \Delta \ln G D P_{t-i}+\sum_{i=0}^{v} \theta_{6} \Delta \operatorname{lnINFR_{t-i}}+\sum_{i=0}^{w} \theta_{7} \Delta \ln U E M R_{t-i}+\sum_{i=0}^{z} \theta_{8} \Delta l n E X C R_{t-i} \\
& +\lambda_{1} \operatorname{lnGREV}_{t-1}+\lambda_{2} \operatorname{lnGEXP_{t-1}}+\lambda_{3} \operatorname{lnOILP}_{t-1}+\lambda_{4} \operatorname{lnGDP_{t-1}}+\lambda_{5} \ln E X T R_{t-1} \\
& +\lambda_{6} \operatorname{lnINFR}_{t-1}+\lambda_{7} \operatorname{lnUEMR}_{t-1}+\lambda_{8} \operatorname{lnEXCR}_{t-1}+\lambda_{9} \text { Dummy }
\end{aligned}
$$

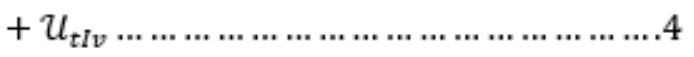




$$
\begin{aligned}
& \Delta l n I N F R_{t}=\pi_{0} \sum_{i=1}^{p} \pi_{1} \Delta \operatorname{lnINFR_{t-i}}+\sum_{i=0}^{q} \pi_{2} \Delta \ln G R E V_{t-i}+\sum_{i=0}^{r} \pi_{3} \Delta \operatorname{lnOILP_{t-i}} \sum_{i=0}^{s} \pi_{4} \Delta \ln G E X P_{t-i} \\
& +\sum_{i=0}^{u} \pi_{5} \Delta \ln G D P_{t-i}+\sum_{i=0}^{v} \pi_{6} \Delta \ln E X T R_{t-i}+\sum_{i=0}^{w} \pi_{7} \Delta \ln U E M R_{t-i}+\sum_{i=0}^{z} \pi_{8} \Delta \ln E X C R_{t-i} \\
& +\lambda_{1} \operatorname{lnGREV}_{t-1}+\lambda_{2} \operatorname{lnGEXP_{t-1}}+\lambda_{3} \operatorname{lnOILP}_{t-1}+\lambda_{4} \operatorname{lnGDP}_{t-1}+\lambda_{5} \ln \operatorname{EXTR}_{t-1} \\
& +\lambda_{6} \operatorname{lnINFR}_{t-1}+\lambda_{7} \operatorname{lnUEMR}_{t-1}+\lambda_{8} \operatorname{lnEXCR}_{t-1}+\lambda_{9} \text { Dummy }
\end{aligned}
$$

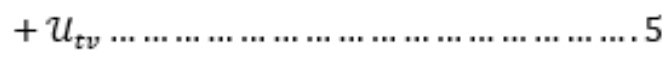

$$
\begin{aligned}
& \Delta \ln U E M R_{t}=\rho_{0} \sum_{i=1}^{p} \rho_{1} \Delta \ln U E M R_{t-i}+\sum_{i=0}^{q} \rho_{2} \Delta \ln G R E V_{t-i}+\sum_{i=0}^{r} \rho_{3} \Delta \ln O I L P_{t-i} \sum_{i=0}^{s} \rho_{4} \Delta \ln G E X P_{t-i} \\
& +\sum_{i=0}^{u} \rho_{5} \Delta \ln G D P_{t-i}+\sum_{i=0}^{v} \rho_{6} \Delta \ln E X T R_{t-i}+\sum_{i=0}^{w} \rho_{7} \Delta \ln I N F R_{t-i}+\sum_{i=0}^{z} \rho_{8} \Delta \ln E X C R_{t-i} \\
& +\lambda_{1} \operatorname{lnGREV}_{t-1}+\lambda_{2} \operatorname{lnGEXP}_{t-1}+\lambda_{3} \operatorname{lnOILP}_{t-1}+\lambda_{4} \operatorname{lnGDP}_{t-1}+\lambda_{5} \ln E X T R_{t-1} \\
& +\lambda_{6} \operatorname{lnINFR}_{t-1}+\lambda_{7} \operatorname{lnUEMR}_{t-1}+\lambda_{8} \operatorname{lnEXCR}_{t-1}+\lambda_{9} \text { Dummy }
\end{aligned}
$$

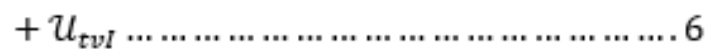

Where $\quad E C M$ is the error correction term lagged for one period;

$\varphi$ is the coefficient for measuring the speed of adjustment

$$
\Delta \text { is the first differencing operator }
$$

$\alpha, \beta, \gamma, \theta, \pi, \rho$ are the coefficients of the shortrun models

While $\lambda$ is the coefficient of the longrun models

Dummy is the dummy variable used to capture oil price decline

" 1 " was used to capture the period when oil price declines and " 0 " was used when otherwise.

However, the Error Correction Models (ECM) are estimated in order to analyse the short run determinants of the effect of declining oil price on the macroeconomic variables in Angola. This would also help in determining the speed of adjustment over time.

\subsection{The Empirical Results}

\subsection{Line Graphs and Descriptive Statistics of the Data}

Relationships among various data of any model are commonly presented visually using graphs since some data are usually too voluminous and complicated to be presented using texts. Aside from revealing the relationship between the different variables, graphs also indicate the direction of the curves. However, all the macroeconomic variables graphically analysed to determine if there are distinct visual trends or not.

The line graphs and the descriptive statistics of the data are as presented below: 
Figure 4. 2: Multiple Line Graphs for Angola

\section{OG(AEXP)}



LOG(GDP)

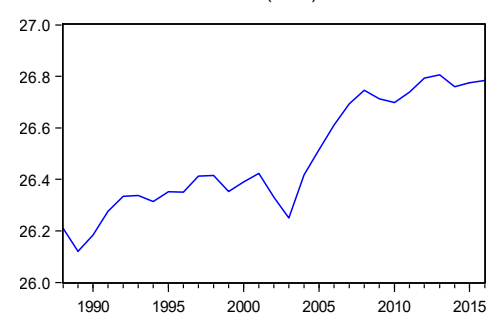

UEMR

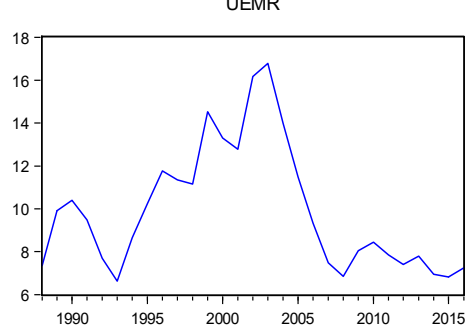

LOG(AREV)

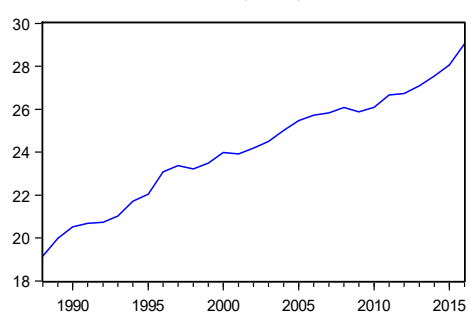

LOG(EXTR)

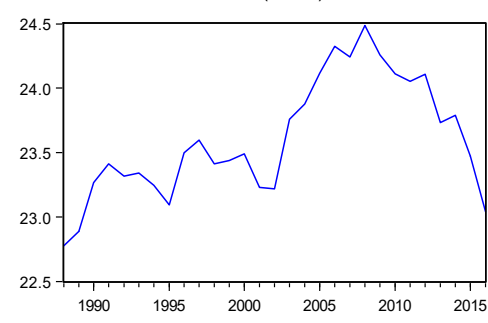

LOG(EXCR)

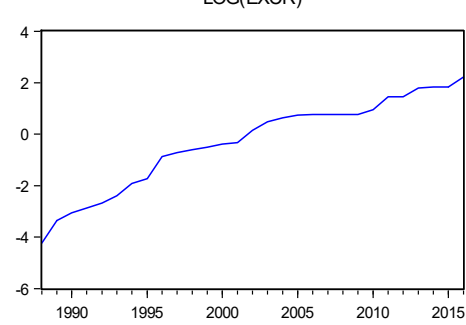

LOG(OILP)

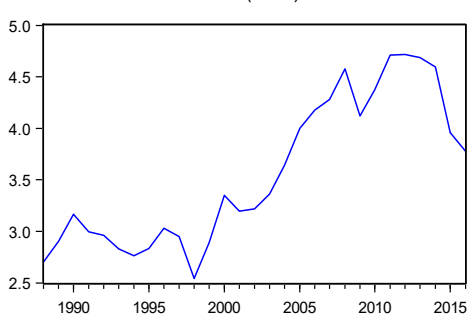

INFR

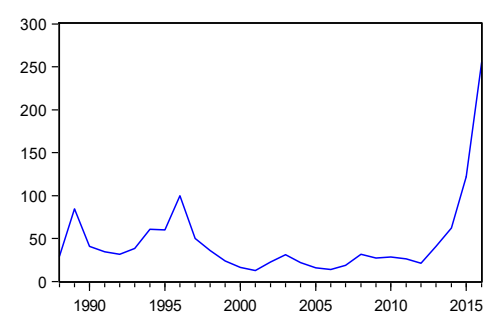

FBAL

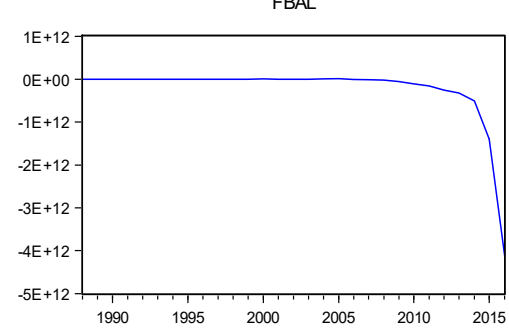

Source: Author's construction using E-Views 10.0

Table 4. 1: Descriptive Statistics of the Data for Angola

\begin{tabular}{|c|c|c|c|c|}
\hline & \multicolumn{1}{l|}{ Min } & \multicolumn{1}{l|}{ Max } & Mean & St. Dev. \\
\hline OILP (\$/barrel) & 12.71 & 111.70 & 45.50 & 33.49 \\
\hline & & & & \\
\hline GEXP(\$b) & 0.30 & 8260.01 & 559.00 & 1600.00 \\
\hline & & & & \\
\hline GREV (\$b) & 0.20 & 4150.00 & 319.00 & 809.00 \\
\hline & & & & \\
\hline GDP (\$b) & 221.03 & 438.00 & 326.00 & 71.40 \\
\hline & & & & \\
\hline EXCR (A0A/\$) & 0.00 & 9.30 & 2.00 & 2.40 \\
\hline & & & & \\
\hline EXTR (\$b) & 7.80 & 43.10 & 19.80 & 9.40 \\
\hline & & & & \\
\hline INFR (\%) & 12.50 & 254.90 & 46.70 & 47.70 \\
\hline & & & & \\
\hline UEMR (\%) & 6.60 & 16.80 & 9.90 & 2.90 \\
\hline
\end{tabular}

Source: Author's construction using E-Views 10.0 
The above Table 4.2 presents the descriptive statistics of the macroeconomic variables for Angola. Oil price ranged from $\$ 12.70$ per barrel to $\$ 111.70$ per barrel. Averagely, oil price was $\$ 45.50$ per barrel and has a deviation of $\$ 33.49$ per barrel. The lowest government expenditure in Angola was $\$ 0.30$ billion, and the highest was $\$ 8260.01$ billion. Government expenditure on the average was $\$ 559.00$ billion, with a deviation of $\$ 1600.00$ billion. Government revenue ranged from $\$ 0.20$ billion to $\$ 4,150.00$ billion. On average, government revenue was $\$ 319$ billion, with a deviation of $\$ 809$ billion. GDP ranged from $\$ 221.00$ billion to $\$ 438.00$ billion, with an average and standard deviation of $\$ 326.00$ billion and $\$ 71.40$ billion. External reserves ranged from $\$ 7.80$ billion to $\$ 43.10$. External reserves stood at $\$ 19.80$ billion on the average, with a deviation of $\$ 9.40$ billion. More so, the exchange rate ranged from $0 \mathrm{AOA} / \$$ to $9.30 \mathrm{AOA} / \$$ and had an average of $2.00 \mathrm{AOA} / \$$ with a standard deviation of $2.40 \mathrm{AOA} / \$$. The inflation rate was around 12.50 percent to 254.90 percent, with the mean and standard deviation of 46.70 percent and 47.70 percent respectively. The unemployment rate was as low as 6.60 percent and high at 16.80 percent. On the average, the unemployment rate was 9.90 percent, and a standard deviation of 2.9 percent.

\subsection{Diagnostic Tests}

The diagnostic tests were effectively carried out before the underlying ARDL models were estimated. These diagnostic tests include:

- $\quad$ Structural and dynamic stability tests (CUSUM and CUSUM of Squares)

- $\quad$ Residual Diagnostics (Heteroscedasticity, Serial Correlation, Normality tests)

- Coefficient Diagnostics \{Long-Run Form and Bound Test; Error Correction Form (Short-Run Test)\}

Also, the Stability tests indicate that the regression equations are stable over time, because the plotted graphs lie within the critical boundaries at 5\% significant level and as such, we cannot reject the null hypothesis that all the coefficients of the Error Correction Models are stable at that level (Thao and Hua, 2016; Yakubu et al., 2014. The residual diagnostic tests were carried out and includes:

- Heteroscedasticity tests

- $\quad$ Serial Correlation tests and

- $\quad$ Normality tests

The Breusch-Godfrey LM test for serial correlation shows that there is no serial correlation while the variances of the error term are constant over time. Also, under non-normality condition, homoscedasticity and independent of the observations of error term produces wrong results (Jargue and Bera, 1982). The results therefore shows that there is no significant departure from the normality.

Additionally, the coefficient diagnostics includes both the long-run (Bound Test) and the Error Correction Form (Short-run Tests) which were also carried out. However, the long-run relationship is based on the Wald-test (F-Statistics) with two critical values (lower and upper critical values), Pesaran et al., (2001). The lower critical bound assumes that all the variables of the model are integrated at level $\mathrm{I}(0)$, which shows that there is no cointegration among the variables of the model but the upper bound assumes that all the variables of the model are integrated at first difference I(1) and this means that there is cointegration among the variables of the model. If the calculated F-Statistic is higher than the upper bound critical value, it then leads to the rejection of the null hypothesis $\left(\mathrm{H}_{0}\right)$; this then shows that the variables of the model are cointegrated. On the contrary, when the calculated F-statistic is below the lower bound critical value, we cannot reject the null hypothesis $\left(\mathrm{H}_{0}\right)$, which shows that there is no cointegration among the variables of the model. When the calculated F-statistic test lies inbetween the lower and the upper bound critical values, the outcomes are said to be inconclusive which means that the relationship between the variables cannot be established (Matlasedi, 2017). However, the Error Correction Model (ECM), was developed to test for the speed of adjustment and to determine how the variables converge towards the equilibrium in the long run. All these tests were carried out and summarised in Appendix A, B, C and D. 


\subsection{Summary of Results, Discussion of Major Findings and Conclusion}

Table 4.4: Table for the Secondary Data Results

\begin{tabular}{|l|l|}
\hline VARIABLES OF THE MODEL & $\begin{array}{l}\text { THE EFFECT OF DECLINING OIL PRICE ON THE } \\
\text { MACROECONOMIC VARIABLES IN ANGOLA }\end{array}$ \\
\hline EXTERNAL RESERVES (EXTR) & $\begin{array}{l}\text { Declining oil price decreases external reserves in the short run } \\
\text { while in the long run, a percentage increase in government } \\
\text { expenditures decreased the external reserves significantly. }\end{array}$ \\
\hline EXCHANGE RATE (EXCR) & A control Variable \\
\hline ECONOMIC GROWTH (GDP) & $\begin{array}{l}\text { Declining oil price exerts a negative and significant effect on } \\
\text { economic growth through the external reserves in the short run. }\end{array}$ \\
\hline GOVERNMENT EXPENDITURES (GEXP) & $\begin{array}{l}\text { The decline in oil revenue increased the government } \\
\text { expenditures in both the short run and the long run respectively. }\end{array}$ \\
\hline INFLATION RATE (INFR) & $\begin{array}{l}\text { Exchange rate depreciation affects the inflation rate positively } \\
\text { in the short run while increasing unemployment led to } \\
\text { reduction in inflation rate in the long run. }\end{array}$ \\
\hline GOVERNMENT REVENUE (GREV) & $\begin{array}{l}\text { A percentage decline in oil price reduces government revenue } \\
\text { in the short run, while unemployment is the main determinant } \\
\text { of government revenue in the long run. }\end{array}$ \\
\hline UNEMPLOYMENT RATE (UEMR) & $\begin{array}{l}\text { Declining oil revenue affects the unemployment rate positively } \\
\text { and significantly. A percentage decline in oil revenue increases } \\
\text { the unemployment rate significantly. }\end{array}$ \\
\hline & \\
\hline
\end{tabular}

Source: Author's design from E-Views 10 analysis of the ARDL model

4.3.1 Summary of Findings from the Secondary Data Analysis for the Angolan Economy

The results for the Angolan economy reveal that in the short run, declining oil price have a negative and significant impact on external reserves, government revenue, economic growth. While unemployment is the primary determinant of government revenue in the long run, government revenue falls for one percent increase in unemployment. Also, in the long run, a percentage increase in government expenditure depletes the external reserves. There is a need for the Angolan government to embrace other alternative sources of revenue rather than borrowing, the printing of currency and depletion of their external reserves in financing its budget deficits. The results also reveal that declining oil revenue has a positive and significant effect on government expenditures and unemployment in both the long-run and short-run, indicating that the Angolan government finances its fiscal needs mainly through borrowing and oil revenue. This also shows that declining oil revenue has a significant impact on the unemployment rate of the Angolan economy. 
4.3.2 Summary of Findings from the Primary Data Analysis for the Angolan Economy The graphs

DECLINING OIL PRICE IMPACT ON THE ANGOLAN ECONOMY

Q1 Increasing oil revenue increases the revenue base of the economy.

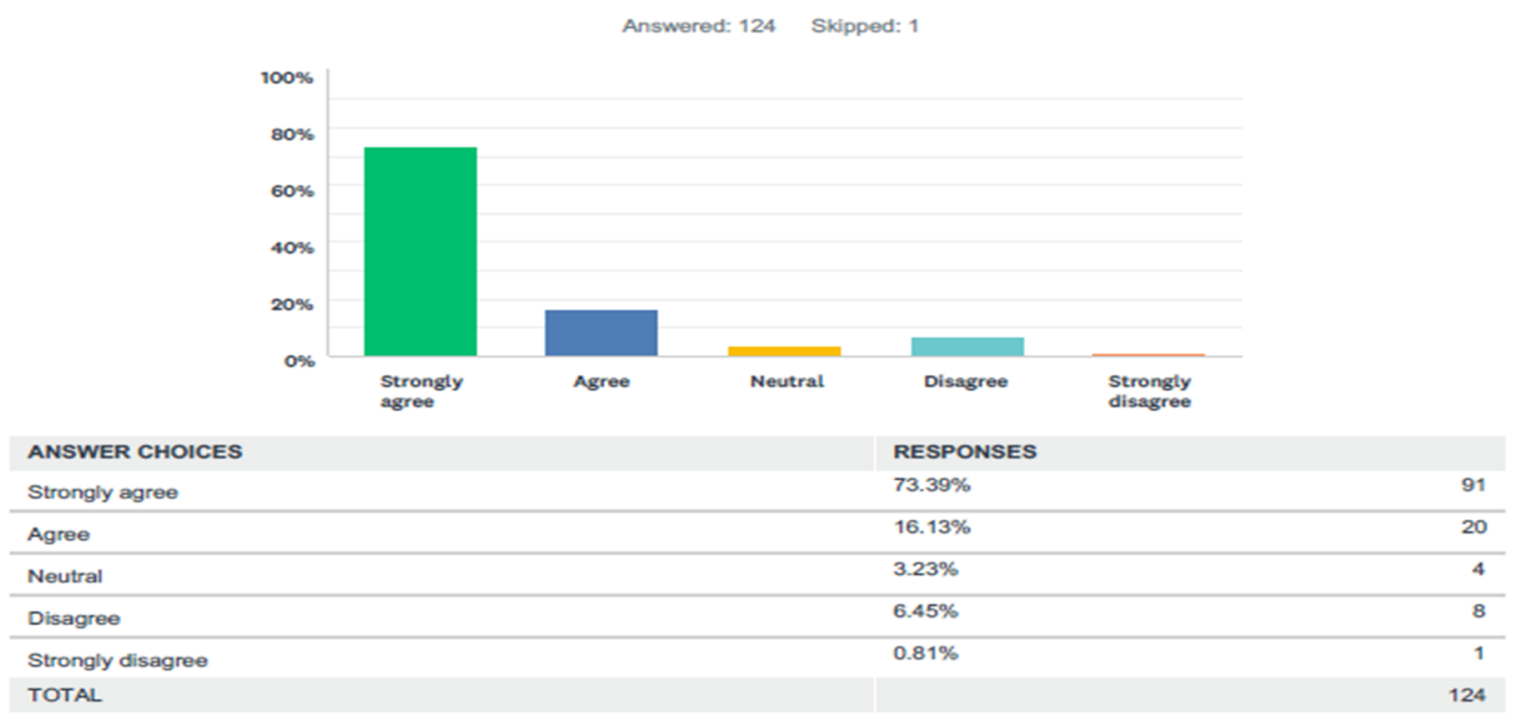

DECLINING OIL PRICE IMPACT ON THE ANGOLAN ECONOMY

\section{Q2 Declining oil revenue adversely affects the economic performance of} the nation.

Answered: 124 Skipped: 1

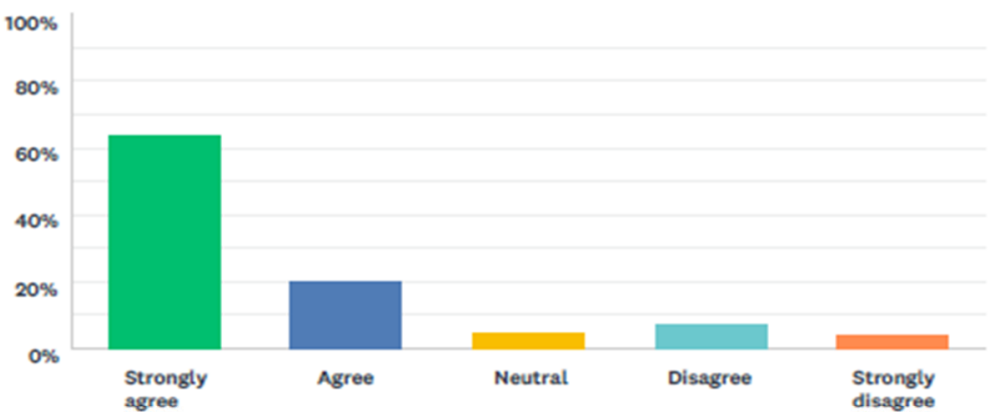

\begin{tabular}{|c|c|c|}
\hline ANSWER CHOICES & RESPONSES & \\
\hline Strongly agree & $63.71 \%$ & 79 \\
\hline Agree & $20.16 \%$ & 25 \\
\hline Neutral & $4.84 \%$ & 6 \\
\hline Disagree & $7.26 \%$ & 9 \\
\hline Strongly disagree & $4.03 \%$ & 5 \\
\hline TOTAL & & 124 \\
\hline
\end{tabular}

Source: Author's computation using Survey Monkey Analysis 
DECLINING OIL PRICE IMPACT ON THE ANGOLAN ECONOMY

Q3 There is a need for other sources of revenue to be explored as a supportive effort in meeting the budgetary needs of the nation.

Answered: 124 Skipped: 1

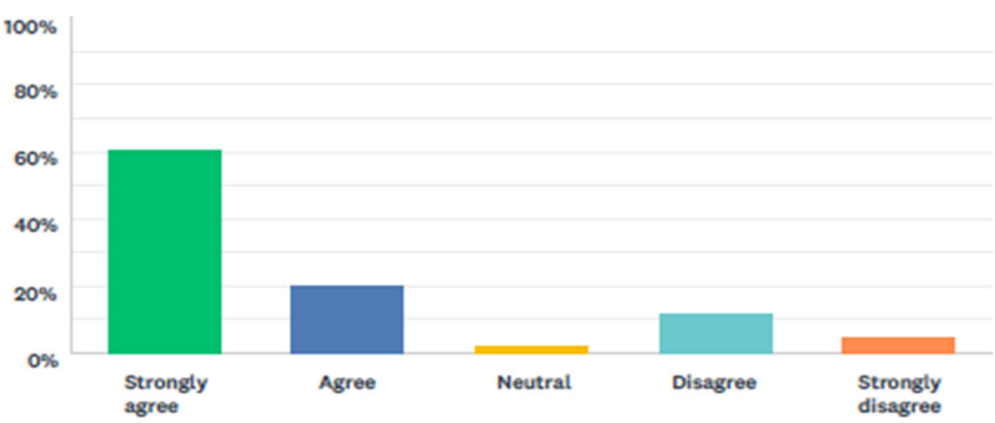

\begin{tabular}{llr} 
ANSWER CHOICES & RESPONSES & 75 \\
\hline Strongly agree & $60.48 \%$ & 25 \\
\hline Agree & $20.16 \%$ & 3 \\
\hline Neutral & $2.42 \%$ & 15 \\
\hline Disagree & $12.10 \%$ & 6 \\
\hline Strongly disagree & $4.84 \%$ & 124
\end{tabular}

DECLINING OIL PRICE IMPACT ON THE ANGOLAN ECONOMY

Q4 The Angolan government makes adequate efforts to explore alternative means of generating revenue in times of declining oil revenues to meet its budgetary needs.

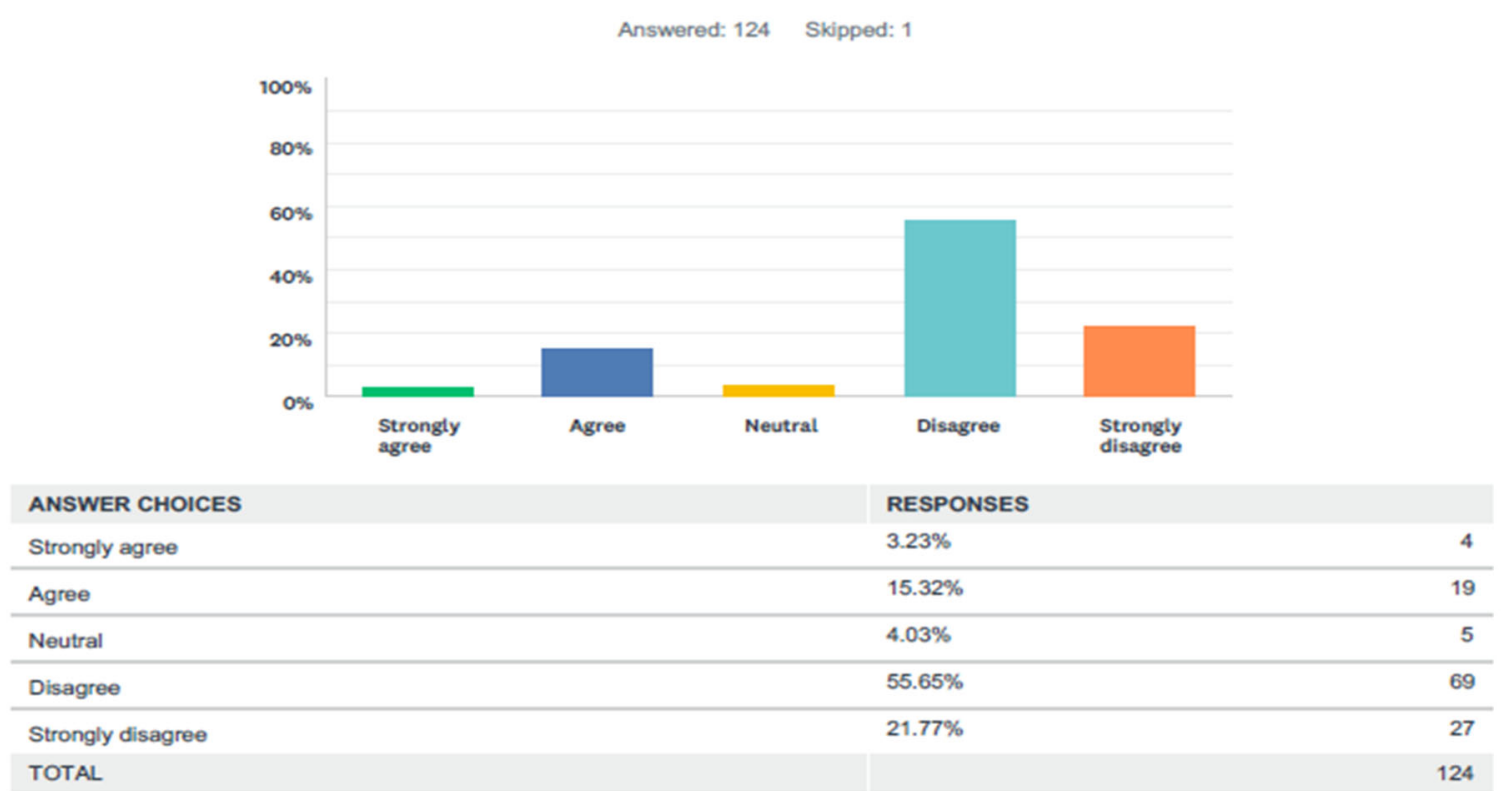

Source: Author's computation using Survey Monkey Analysis 
DECLINING OIL PRICE IMPACT ON THE ANGOLAN ECONOMY

Q5 The Angolan government utilises the nation's natural resources efficiently.

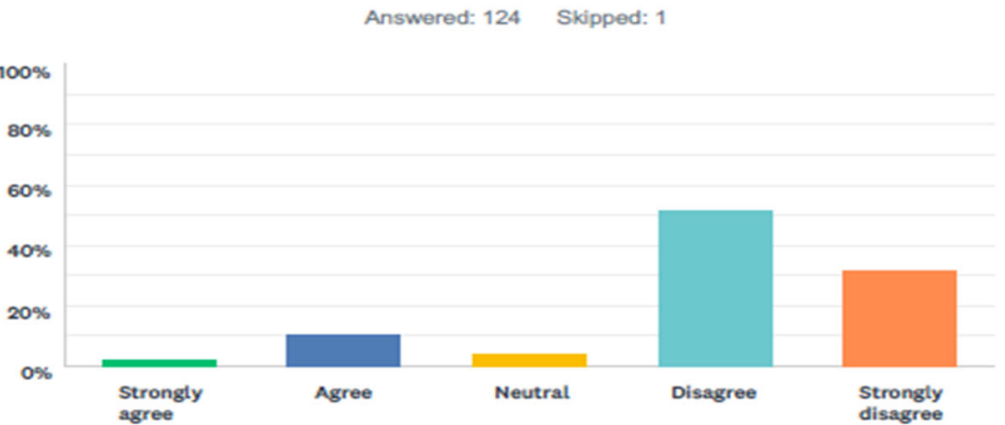

\begin{tabular}{l|rr}
\hline ANSWER CHOICES & RESPONSES & 3 \\
\hline Strongly agree & $2.42 \%$ & 13 \\
\hline Agree & $10.48 \%$ & 5 \\
\hline Neutral & $4.03 \%$ & 64 \\
\hline Disagree & $51.61 \%$ & 39 \\
\hline Strongly disagree & $31.45 \%$ & 124
\end{tabular}

DECLINING OIL PRICE IMPACT ON THE ANGOLAN ECONOMY

Q6 The government handles the nation's budgetary problems effectively.

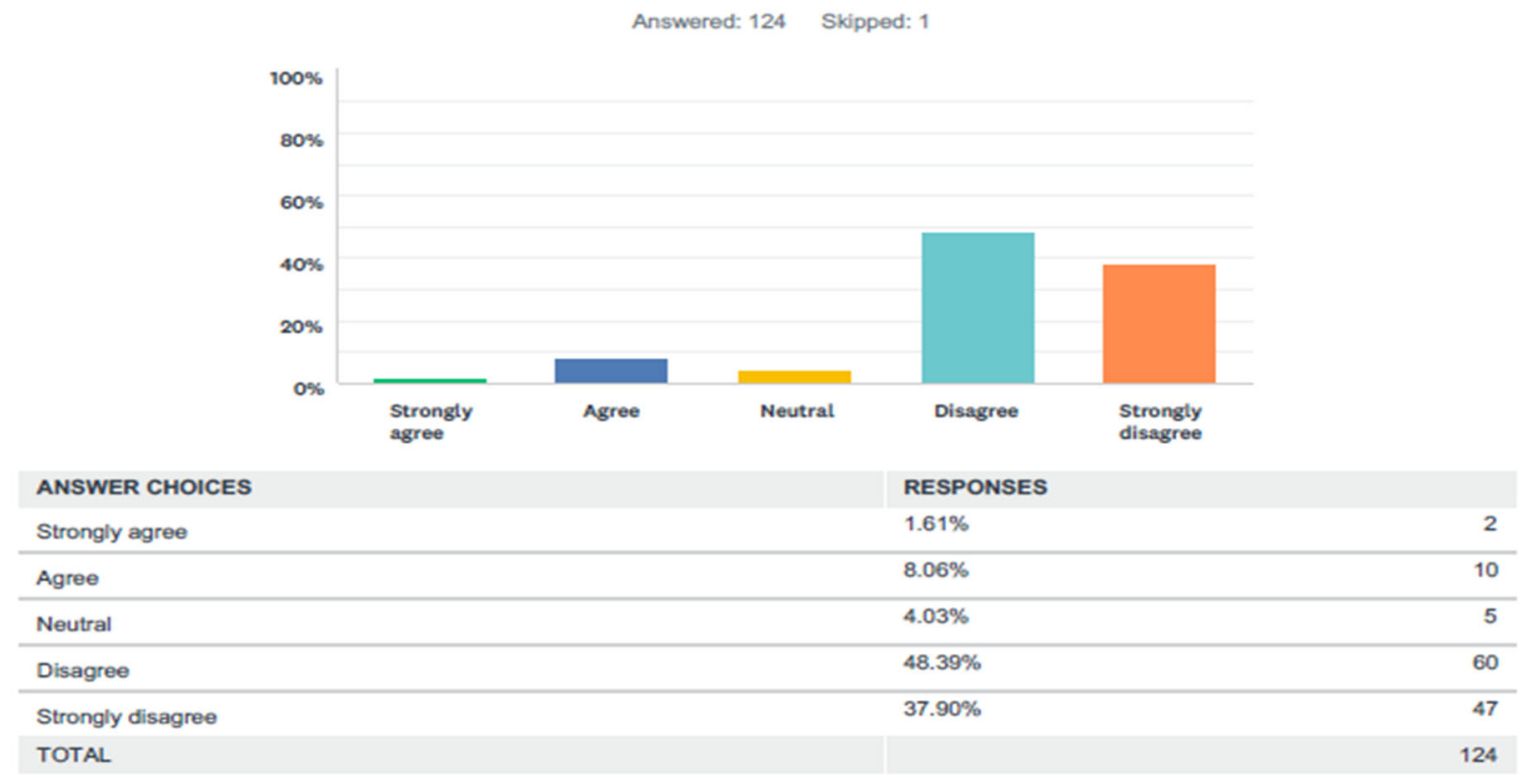

Source: Author's computation using Survey Monkey Analysis 
DECLINING OIL PRICE IMPACT ON THE ANGOLAN ECONOMY

Q7 When decisions to increase or reduce the budget of the Angolan economy are made, the government explains to the populace the reasons for such decision.

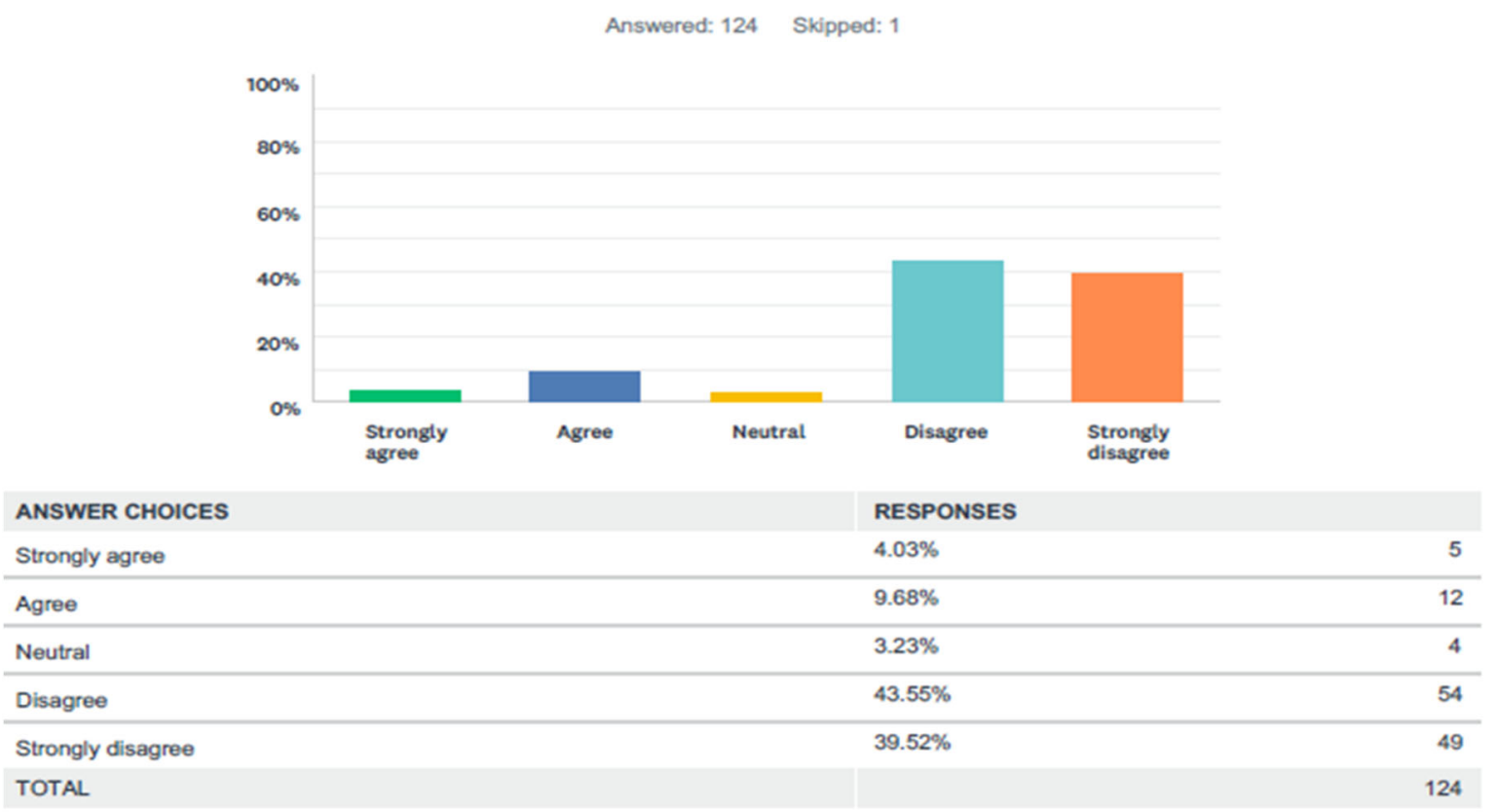

DECLINING OIL PRICE IMPACT ON THE ANGOLAN ECONOMY

Q8 The management of the Angolan government budget is very effective.

Answered: 124 Skjpped: 1



\begin{tabular}{llr} 
ANSWER CHOICES & RESPONSES & 5 \\
\hline Strongly agree & $4.03 \%$ & 13 \\
\hline Agree & $10.48 \%$ & 4 \\
\hline Neutral & $3.23 \%$ & 46 \\
\hline Disagree & $37.10 \%$ & 56 \\
\hline Strongly disagree & $45.16 \%$ & 124 \\
TOTAL & & 5
\end{tabular}

Source: Author's computation using Survey Monkey Analysis

Questions 9 and 10 are the open-ended questions. Unlike the closed-ended questions, the structure of the open-ended questions are straight-forward responses and does not require any form of transformation given that they represent the respondents' opinions. The dominant responses with the highest frequency were selected. 
Question 9 seeks to know how Angola attends its budgetary needs during periods of declining oil revenues; the dominant responses to this question is that the Angolan government resort to seigniorage, internal and external borrowing in order to meet with the budgetary needs of the nations. On the other hand, question 10 seeks to know what the Angolan government need to do to improve its revenue base and budgetary performance in times of declining oil revenue. The dominant responses to this question entail that the government should diversify the economy and reduce over-reliance on oil, prevent capital flight from Angola, develop their human capital, shun corruption, develop other natural resources in Angola and invest in other sectors of the economy.

From the graphs, the result shows that the government revenue of Angola increases as oil price rises while decreasing oil revenue affects the affects the economy adversely. This outcome is highly consistent with the study of (Brock, 2015) which reveal that crude oil accounts for over $90 \%$ of Angola's export earnings. However, the results support the need for the Angolan economy to diversify its revenue base and embrace other source of generating revenue aside oil since the nation is endowed with other natural resources. Results also shows that the Angolan government is not managing the government budget effectively and as such, the nation should adopt a good management system and invest more on human capital development.

4.3.3 Proposed Economic Model for the Angolan Economy

An economic model is proposed, in order to close the revenue gaps in Angola. Economic models are the primary tools which economists employ in explaining economic issues or in making predictions about economic problems and solutions. The models could be in form of graphs, mathematics or in words. Economic models are subjective and is also classified as a simplified way of explaining the complex nature of the real world through different views (Ouliaris, 2018). Milton Friedman conclude that the validity of any economic model can be tested when it is capable of forecasting real world activities (Ouliaris, 2018; Nicholson, 2007).

However, from figure 5.1, the cheaper oil exports led to the increase in aggregate demand for oil, which inturn brought about declining oil income, as such, highly oil dependent nations are unable to finance the fiscal needs of the nation. The imports become so expensive due to weak exchange rate, hence, drastic reduction of imports, which would also lead to the improvement in the production of local goods by the domestic industries. There would be a ripple effect of economic diversification and reduction in the rate of unemployment. There is need for human capital development and good management system so as to manage both the oil and non-oil income effectively, which would eventually increase the external reserves, improved balance of trade, economic growth and development of the Angolan economy.

Figure 5. 1: Proposed Economic Model for Angola

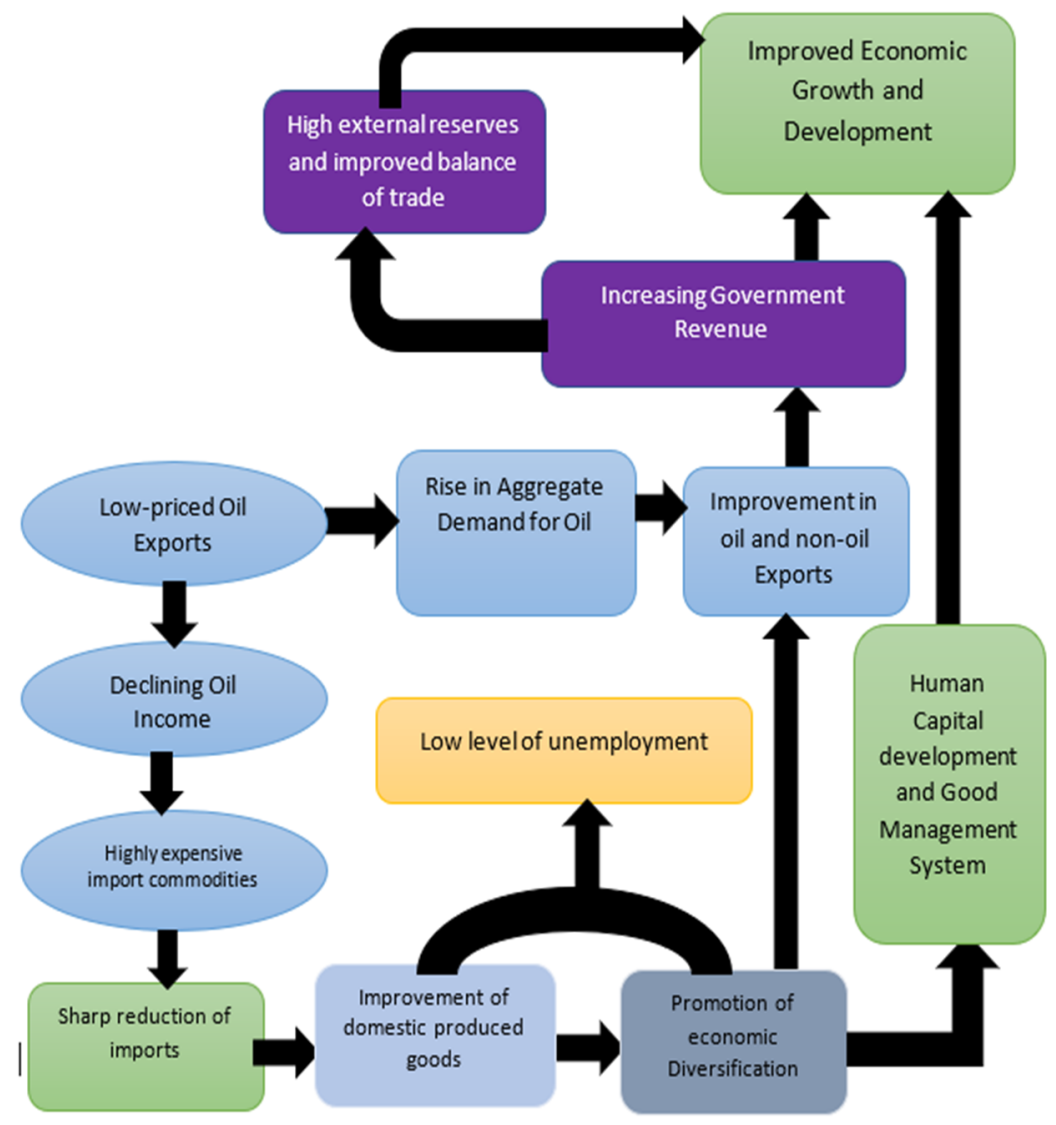

Source: Author's design 


\subsection{Conclusion and Recommendations}

This study analysed the ordeal of a petrostate, Angola, amidst declining oil revenue as the economy is highly dependent on oil export for its sustainability. While the secondary data were analysed using the ARDL estimation technique, the primary data were sourced through questionnaires, to supplement the secondary data analysis. The results reveal that declining oil price have negative and significant impact on government revenue and the external reserves of the economy which indicate that Angola is overwhelmingly dependent on oil exports in order to meet with the budgetary objectives of the nation. However, since there is a significant decrease in the revenue base of Angola as oil price falls, there is need for a good policy reforms which would promote economic diversification in the economy and this could also help other nations that are highly dependent on oil revenue. There is also need for a policy measure which would help in reshaping the spending habit in Angola; so as to combat the resource curse syndrome that has ravaged Angola and similar nations. Finally, there is evidence of spend-revenue hypothesis and revenue-spend hypothesis; hence there is need for Angola and similar countries to consider determining both the government revenues and government expenditures concurrently. This would effectively help to deal with the budget deficits that has ravaged the economy.

\section{Appendices}

Appendix A: Unit Root Test Result for Angola

\begin{tabular}{|c|c|c|c|c|c|c|c|c|c|}
\hline & & \multicolumn{4}{|c|}{ AUGMENTED DICKEY FULLER TEST (ADF) } & \multicolumn{4}{|c|}{ PHILLIPS-PERRON TEST (PPT) } \\
\hline & & Intercept & SS & $\begin{array}{l}\text { Intercept \& } \\
\text { Trend }\end{array}$ & SS & Intercept & SS & $\begin{array}{l}\text { Intercept \& } \\
\text { Trend }\end{array}$ & SS \\
\hline \multirow[t]{2}{*}{ GEXP } & Levels & $0.7016(0.89)$ & \multirow[t]{2}{*}{$\mathrm{I}(1)$} & $-1.078-0.9123$ & \multirow[t]{2}{*}{$\mathrm{I}(1)$} & $\begin{array}{l}0.5219 \\
(0.9878) \\
\end{array}$ & \multirow[t]{2}{*}{$\mathrm{I}(1)$} & $\begin{array}{l}-1.3327 \\
(0.8283) \\
\end{array}$ & \multirow[t]{2}{*}{$\mathrm{I}(1)$} \\
\hline & $\begin{array}{l}1^{\text {st }} \text { Diff } \\
(\Delta)\end{array}$ & $\begin{array}{l}-3.3295 \\
(0.0224)^{* *}\end{array}$ & & $\begin{array}{l}-3.3107 \\
(0.0859)^{*}\end{array}$ & & $\begin{array}{l}-3.3295 \\
(0.0234)^{* *}\end{array}$ & & $\begin{array}{l}-3.3107 \\
(0.0859)^{*}\end{array}$ & \\
\hline \multirow[t]{2}{*}{ GREV } & Levels & $\begin{array}{l}-0.455 \\
(0.8657)\end{array}$ & \multirow[t]{2}{*}{$\mathrm{I}(1)$} & $\begin{array}{l}-2.4776- \\
0.3352\end{array}$ & \multirow[t]{2}{*}{$\mathrm{I}(1)$} & $\begin{array}{l}-0.4613 \\
(0.8847)\end{array}$ & \multirow[t]{2}{*}{$\mathrm{I}(1)$} & $\begin{array}{l}-2.4786 \\
(0.3352)\end{array}$ & \multirow[t]{2}{*}{$\mathrm{I}(1)$} \\
\hline & $\begin{array}{l}1^{\text {st }} \text { Diff } \\
(\Delta)\end{array}$ & $\begin{array}{l}-4.1743 \\
(0.0031)^{+* *}\end{array}$ & & $\begin{array}{l}-3.952 \\
(0.0234)^{* *}\end{array}$ & & $\begin{array}{l}-4.132 \\
(0.0036)^{*+*}\end{array}$ & & $\begin{array}{l}-3.8762 \\
(0.0275)^{* *}\end{array}$ & \\
\hline \multirow[t]{2}{*}{ EXCR } & Levels & $4.3268(1.00)$ & \multirow[t]{2}{*}{ NS } & $2.6425(1.00)$ & \multirow[t]{2}{*}{$\mathrm{I}(1)$} & $4.0762(1.00)$ & \multirow[t]{2}{*}{$\mathrm{I}(1)$} & $\begin{array}{l}1.7404 \\
(1.00)\end{array}$ & \multirow[t]{2}{*}{$\mathrm{I}(1)$} \\
\hline & $\begin{array}{l}1^{\text {st }} \text { Diff } \\
(\Delta)\end{array}$ & $\begin{array}{l}-0.1183- \\
0.9362\end{array}$ & & $\begin{array}{l}-3.6448 \\
(0.0469)^{* *}\end{array}$ & & $\begin{array}{l}-3.86 \\
(0.0068)^{*+*}\end{array}$ & & $\begin{array}{l}-5.3595 \\
(0.0009)^{*+*}\end{array}$ & \\
\hline \multirow[t]{2}{*}{ EXTR } & Levels & $\begin{array}{l}-1.7539- \\
0.3946 \\
\end{array}$ & \multirow[t]{2}{*}{$\mathrm{I}(1)$} & $\begin{array}{l}-0.2661 \\
(0.987) \\
\end{array}$ & \multirow[t]{2}{*}{$\mathrm{I}(1)$} & $\begin{array}{l}-1.909 \\
(0.3236) \\
\end{array}$ & \multirow[t]{2}{*}{$\mathrm{I}(1)$} & $\begin{array}{l}-0.5557 \\
(0.974) \\
\end{array}$ & \multirow[t]{2}{*}{$\mathrm{I}(1$} \\
\hline & $\begin{array}{l}1^{\text {st }} \text { Diff } \\
(\Delta)\end{array}$ & $\begin{array}{l}-3.8901 \\
(0.0050)^{*+*}\end{array}$ & & $\begin{array}{l}-4.5725 \\
(0.0059)^{* * *}\end{array}$ & & $\begin{array}{l}-3.9702 \\
(0.0053)^{*+*}\end{array}$ & & $\begin{array}{l}-4.5785 \\
(0.0058)^{*+*}\end{array}$ & \\
\hline \multirow[t]{2}{*}{ GDP } & Levels & $\begin{array}{l}-0.6605 \\
(0.8409)\end{array}$ & \multirow[t]{2}{*}{$\mathrm{I}(1)$} & $\begin{array}{l}-2.6619 \\
(0.2586) \\
\end{array}$ & \multirow[t]{2}{*}{$\mathrm{I}(1)$} & $\begin{array}{l}-0.5882 \\
(0.858) \\
\end{array}$ & \multirow[t]{2}{*}{$\mathrm{I}(1)$} & $\begin{array}{l}-2.3408 \\
(0.4001) \\
\end{array}$ & \multirow[t]{2}{*}{$\mathrm{I}(1$} \\
\hline & $\begin{array}{l}1^{\text {st }} \text { Diff } \\
(\Delta)\end{array}$ & $\begin{array}{l}-4.4635 \\
(0.0016)^{+* *}\end{array}$ & & $\begin{array}{l}-4.3674 \\
(0.0092)^{* * *}\end{array}$ & & $\begin{array}{l}-4.4531 \\
(0.0016)^{*+*}\end{array}$ & & $\begin{array}{l}-4.3614 \\
(0.0095)^{*+*}\end{array}$ & \\
\hline \multirow[t]{2}{*}{ INFR } & Levels & $\begin{array}{l}-1.0922- \\
0.7039 \\
\end{array}$ & \multirow[t]{2}{*}{$\mathrm{I}(1)$} & $\begin{array}{l}-0.4159- \\
0.9817 \\
\end{array}$ & \multirow[t]{2}{*}{$\mathrm{I}(1)$} & $\begin{array}{l}-0.6204 \\
(0.8506) \\
\end{array}$ & \multirow[t]{2}{*}{$\mathrm{I}(1)$} & $\begin{array}{l}-0.6471 \\
(0.9676) \\
\end{array}$ & \multirow[t]{2}{*}{$\mathrm{I}(1$} \\
\hline & $\begin{array}{l}1^{\text {st }} \text { Diff } \\
(\Delta)\end{array}$ & $\begin{array}{l}-4.6278 \\
(0.0010)^{* * *}\end{array}$ & & $\begin{array}{l}-5.3797 \\
(0.0009)^{* * *}\end{array}$ & & $\begin{array}{l}-4.7046 \\
(0.0009)^{* * *}\end{array}$ & & $\begin{array}{l}-5.3214 \\
(0.0010)^{*+*}\end{array}$ & \\
\hline \multirow[t]{2}{*}{ OILP } & Levels & $\begin{array}{l}-1.3124- \\
0.6095 \\
\end{array}$ & \multirow[t]{2}{*}{$\mathrm{I}(1)$} & $\begin{array}{l}-1.2191 \\
(0.8868) \\
\end{array}$ & \multirow[t]{2}{*}{$\mathrm{I}(1)$} & $\begin{array}{l}-1.3531 \\
(0.5903) \\
\end{array}$ & $\mathrm{I}(1)$ & $\begin{array}{l}-1.4665 \\
(0.8171) \\
\end{array}$ & $I(1)$ \\
\hline & $\begin{array}{l}1^{\text {st }} \text { Diff } \\
(\Delta)\end{array}$ & $\begin{array}{l}-4.3832 \\
(0.0019)^{*+*}\end{array}$ & & $\begin{array}{l}-4.3613 \\
(0.0095)^{*+*}\end{array}$ & & $\begin{array}{l}-4.3384 \\
(0.0021)^{*+*}\end{array}$ & & $\begin{array}{l}-4.3212 \\
(0.0104)^{* *}\end{array}$ & \\
\hline UEMR & Levels & $\begin{array}{l}-1.8178- \\
0.3643\end{array}$ & $\mathrm{I}(1)$ & $\begin{array}{l}-1.8762 \\
(0.6399)\end{array}$ & $\mathrm{I}(1)$ & $\begin{array}{l}-1.4659 \\
(0.5357)\end{array}$ & $\mathrm{I}(1)$ & $\begin{array}{l}-2.036 \\
(0.5572)\end{array}$ & $\mathrm{I}(1)$ \\
\hline & $\begin{array}{l}1^{\text {st }} \text { Diff } \\
(\Delta)\end{array}$ & $\begin{array}{l}-4.0688 \\
(0.0041)^{+4+}\end{array}$ & & $\begin{array}{l}-3.9024 \\
(0.0260)^{* *}\end{array}$ & & $\begin{array}{l}-4.0506 \\
(0.0043)^{+4+}\end{array}$ & & $\begin{array}{l}-3.868 \\
(0.0280)^{* *}\end{array}$ & \\
\hline
\end{tabular}

$*+4, *$ and $\%$ denote the significant level at $1 \%, 5 \%$ and $10 \%$ respectively

Source: Author's Computation using E-Views 10.0 
Appendix B: Structural and Dynamic Stability Tests for Angola (CUSUM tests)

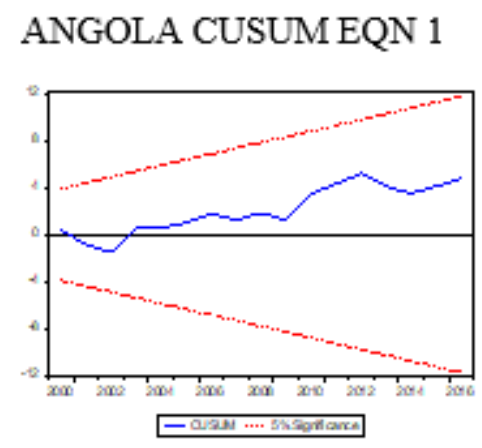

ANGOLA CUSUM EQN 4

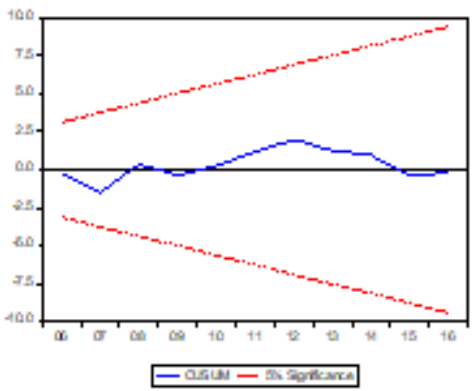

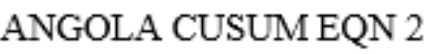

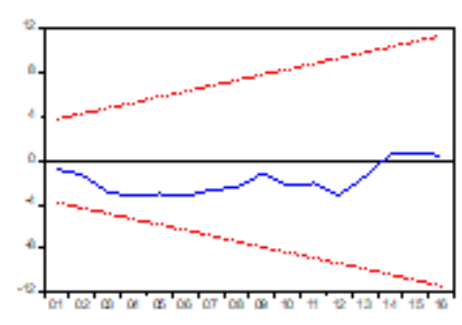

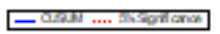

ANGOLA CUSUM EQN 5 ANGOLA CUSUM EQN 6

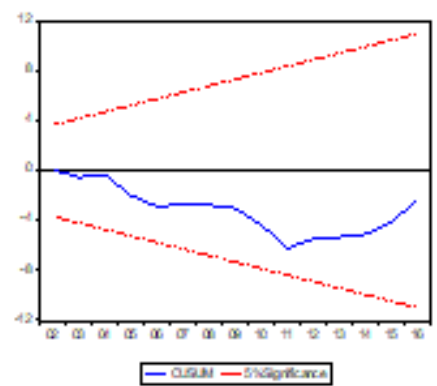

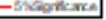

ANGOLA CUSUM EQN 3

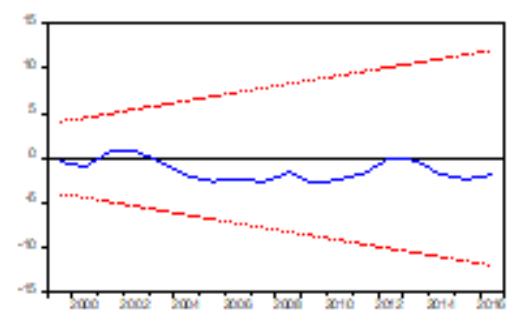

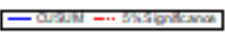

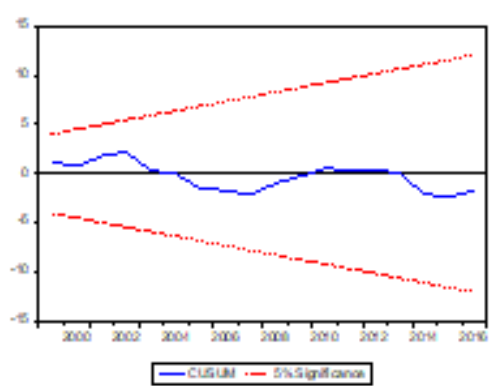

Source: Author's Computation using E-Views 10.0

Appendix C: Structural and Dynamic Stability Tests for Angola (CUSUM of Squares Tests)

ANGOLA CUSUM SQ EQN 1 ANGOLA CUSUM SQ EQN 2 ANGOLA CUSUM SQ EQN 3
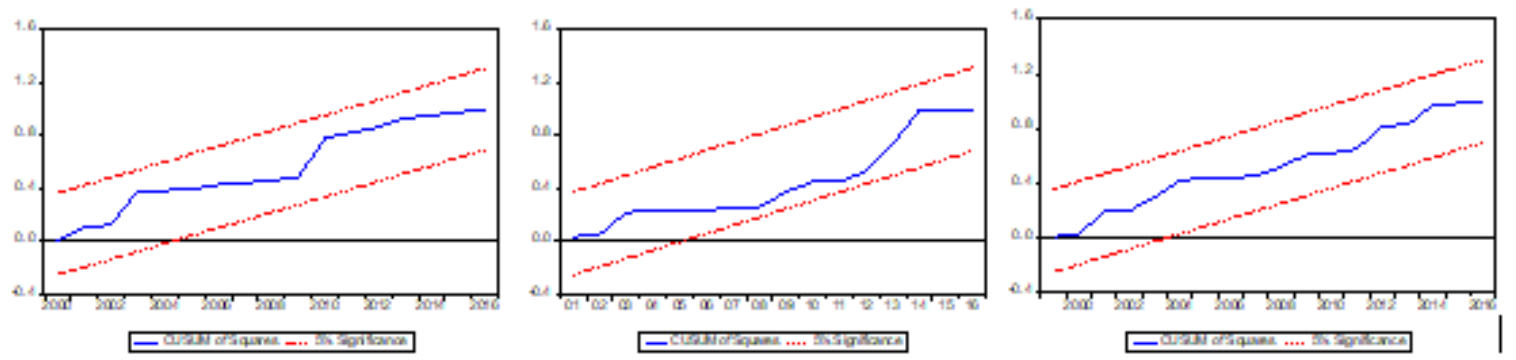

ANGOLA CUSUM SQ EQN 4 ANGOLA CUSUM SQ EQN 5 ANGOLA CUSUM SQ EQN 6
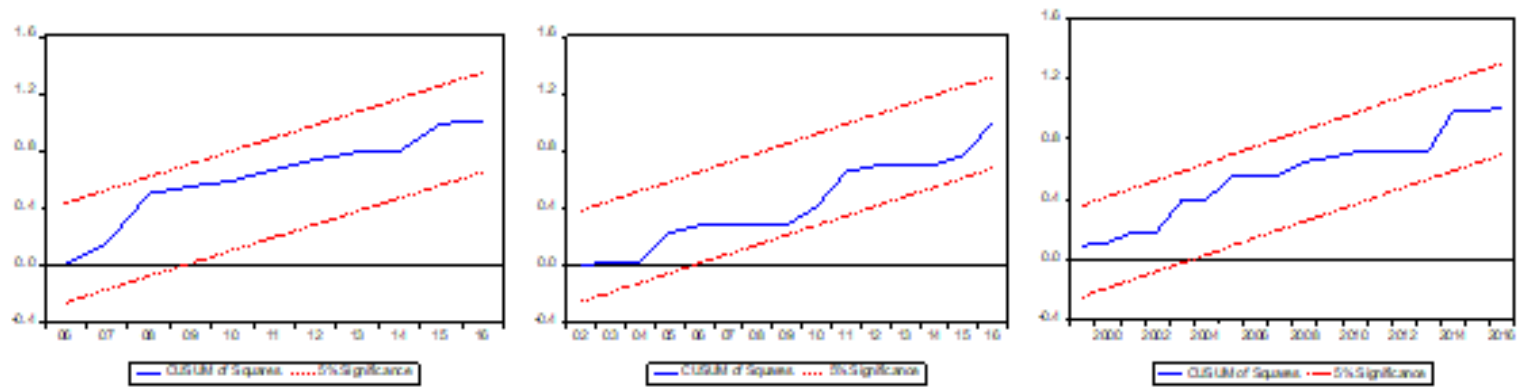

Source: Author's Computation using E-Views 10.0 
Appendix D: Diagnostic Test Results: Coefficient Diagnostics (Long-Run Form and Bound Test; Error Correction Form (Short-Run Test)

Appendix D1: Long-run estimates of the impact of declining oil price on Angola's Budgetary Objectives

\begin{tabular}{|c|c|c|c|c|c|c|c|c|c|c|c|c|}
\hline & GEXP & GREV & GDP & EXTR & INFR & UEMR & GEXP & GREV & GDP & EXTR & INFR & UEMR \\
\hline $\begin{array}{l}\text { LOG(GE } \\
\mathrm{XP})\end{array}$ & & $\begin{array}{l}0.326(0.3 \\
45) \\
\end{array}$ & $\begin{array}{l}0.157^{*}(0.0 \\
94)\end{array}$ & \begin{tabular}{|l|}
$4.366(4.1$ \\
$42)$ \\
\end{tabular} & $\begin{array}{l}35.653(73.7 \\
57)\end{array}$ & $3.33(3.745)$ & & $\begin{array}{l}\text { 1.066(3.7 } \\
6) \\
\end{array}$ & \begin{tabular}{|l|}
- \\
$0.082(0.0$ \\
$69)$ \\
\end{tabular} & $\begin{array}{l} \\
1.469^{*}(0 . \\
819)\end{array}$ & $\begin{array}{l}142.056(10 \\
9.197)\end{array}$ & $\begin{array}{l} \\
3.564^{* *}(1.3 \\
18)\end{array}$ \\
\hline $\begin{array}{l}\text { LOG(OI } \\
\text { LP) }\end{array}$ & $\begin{array}{l}0.036(0.12 \\
2)\end{array}$ & $\begin{array}{l}0.339(0.2 \\
92)\end{array}$ & $\begin{array}{l}0.093^{* 8}(0 . \\
036)\end{array}$ & $\begin{array}{l}2.787(3.0 \\
3) \\
\end{array}$ & $\begin{array}{l}56.887^{8 *}(2 \\
6.625)\end{array}$ & $-0.3(1.359)$ & & & & & & \\
\hline $\begin{array}{l}\text { LOG(G } \\
\text { DP) }\end{array}$ & $\begin{array}{l}- \\
1.336(1.14 \\
7)\end{array}$ & $\begin{array}{l}0.027(1.3 \\
94)\end{array}$ & & $\begin{array}{l} \\
10.02(12 . \\
846)\end{array}$ & $\begin{array}{l} \\
349.173(25 \\
2.73)\end{array}$ & $\begin{array}{l}- \\
25.847^{88 *}( \\
4.502)\end{array}$ & $\begin{array}{l} \\
3.331^{*}(1 \\
742)\end{array}$ & $\begin{array}{l}4.702(7.8 \\
57)\end{array}$ & & $\begin{array}{l}- \\
0.955(3.8 \\
91)\end{array}$ & $\begin{array}{l}607.758(61 \\
2.193)\end{array}$ & $\begin{array}{l}- \\
18.733^{* 8 *}( \\
2.933)\end{array}$ \\
\hline $\begin{array}{l}\text { LOG(EX } \\
\text { TR) }\end{array}$ & $\begin{array}{l}0.422^{* 8 *}( \\
0.136)\end{array}$ & $\begin{array}{l}0.058(0.2 \\
45) \\
\end{array}$ & $\begin{array}{l}0.039(0.03 \\
6) \\
\end{array}$ & & $\begin{array}{l}- \\
47.357(41.5 \\
71) \\
\end{array}$ & $\begin{array}{l}- \\
0.821(1.049 \\
{ }^{2}\end{array}$ & $\begin{array}{l}0.339 * *(0 \\
.147) \\
\end{array}$ & $\begin{array}{l} \\
0.636(1.4 \\
99)\end{array}$ & $\begin{array}{l}0.055(0.0 \\
46) \\
\end{array}$ & & $\begin{array}{l}127.033(11 \\
6.629) \\
\end{array}$ & $\begin{array}{l}2.234^{* *}(0.8 \\
14)\end{array}$ \\
\hline INFR & $0(0.003)$ & $\begin{array}{l}0.008^{8}(0 . \\
004)\end{array}$ & $O(0)$ & \begin{tabular}{|l|}
$0.019(0.0$ \\
$27)$ \\
\end{tabular} & & $\begin{array}{l}0.031 *(0.01 \\
5)\end{array}$ & \begin{tabular}{|l|} 
\\
$0.339 * *(0$ \\
$.147)$ \\
\end{tabular} & $\begin{array}{l} \\
0.636(1.4 \\
99)\end{array}$ & $\begin{array}{l}0.055(0.0 \\
46)\end{array}$ & & $\begin{array}{l}127.033(11 \\
6.629) \\
\end{array}$ & $\begin{array}{l}2.234^{* *}(0.8 \\
14)\end{array}$ \\
\hline UEMR & $\begin{array}{l}0.102^{* *}(0 . \\
031)\end{array}$ & $\begin{array}{l}0.01(0.05 \\
8)\end{array}$ & $\begin{array}{l}0.026^{888}( \\
0.005)\end{array}$ & \begin{tabular}{|l|}
- \\
$0.295(0.3$ \\
$27)$ \\
\end{tabular} & & & $\begin{array}{l}0.044(0.1 \\
09)\end{array}$ & $\begin{array}{l}- \\
0.03^{* 8 *}(0 \\
.006)\end{array}$ & \begin{tabular}{|l|}
- \\
$0.166(0.1$ \\
$39)$ \\
\end{tabular} & $\begin{array}{l}23.234(21 \\
.502)\end{array}$ & $\begin{array}{l}- \\
0.165^{* 8}(0.0 \\
6)\end{array}$ & \\
\hline $\begin{array}{l}\text { LOG(EX } \\
\text { CR) }\end{array}$ & $\begin{array}{l}0.142(0.22 \\
2)\end{array}$ & $\begin{array}{l}0.803(0.4 \\
87) \\
\end{array}$ & $\begin{array}{l}0.039(0.04 \\
)^{2}\end{array}$ & $\begin{array}{l}3.272(3.6 \\
04) \\
\end{array}$ & \begin{tabular}{|l|}
- \\
$18.855^{* *}(8$. \\
$919)$ \\
\end{tabular} & $\begin{array}{l}- \\
0.282(2.086 \\
\end{array}$ & $\begin{array}{l}0.166(0.2 \\
24) \\
\end{array}$ & $\begin{array}{l}1.473(2.4 \\
16)\end{array}$ & $\begin{array}{l}0.006(0.0 \\
49) \\
\end{array}$ & $\begin{array}{l}0.234(0.4 \\
8)\end{array}$ & $\begin{array}{l}7.247(85.57 \\
4)\end{array}$ & $\begin{array}{l}2.62^{* 8}(0.99 \\
7)\end{array}$ \\
\hline $\begin{array}{l}\text { LOG(A } \\
\text { REV) }\end{array}$ & $\begin{array}{l}1.076^{* 8 *}( \\
0.176)\end{array}$ & & $\begin{array}{l}0.007(0.07 \\
3)\end{array}$ & $\begin{array}{l}2.259(2.4 \\
61)\end{array}$ & $\begin{array}{l}11.013(79.1 \\
97)\end{array}$ & )$^{1.807(2.345}$ & $\begin{array}{l}1.22^{* 8 *}(0 \\
.172)\end{array}$ & & $\begin{array}{l}0.142^{*}(0 . \\
081)\end{array}$ & $\begin{array}{l}1.513(1.0 \\
28)\end{array}$ & $\begin{array}{l}75.548(91.8 \\
24)\end{array}$ & $\begin{array}{l}3.548^{* *}(1.6 \\
24)\end{array}$ \\
\hline $\begin{array}{l}\text { Oil } \\
\text { dummy }\end{array}$ & No & No & No & \begin{tabular}{|l|} 
No \\
No
\end{tabular} & No & No & \begin{tabular}{|l|}
.125 \\
Yes
\end{tabular} & Yes & \begin{tabular}{|l|} 
Yes \\
Yes
\end{tabular} & Yes & Yes & Yes \\
\hline
\end{tabular}

Appendix D2: Diagnostic test results for Angola

\begin{tabular}{|l|l|l|l|l|l|l|l|l|l|l|l|l}
\hline Diagnostics & GEXP & GREV & GDP & EXTR & INFR & UEMR & GEXP & GREV & GDP & EXTR & INFR & UEMR \\
\hline Normality test, JB- test & $\begin{array}{l}5.850 \\
(0.033)\end{array}$ & $\begin{array}{l}0.365 \\
(0.837)\end{array}$ & $\begin{array}{l}0.166 \\
(0.911)\end{array}$ & $\begin{array}{l}1.095 \\
(0.578)\end{array}$ & $\begin{array}{l}1.368 \\
(0.505)\end{array}$ & $\begin{array}{l}1.878 \\
(0.391)\end{array}$ & $\begin{array}{l}1.073 \\
(0.585)\end{array}$ & $\begin{array}{l}0.933 \\
(0.627)\end{array}$ & $\begin{array}{l}0.406 \\
(0.816)\end{array}$ & $\begin{array}{l}0.085 \\
(0.954)\end{array}$ & $\begin{array}{l}1.232 \\
(0.540)\end{array}$ & $\begin{array}{l}1.366 \\
(0.505)\end{array}$ \\
\hline & $\begin{array}{l}0.410 \\
(0.526)\end{array}$ & $\begin{array}{l}0.355 \\
(0.556)\end{array}$ & $\begin{array}{l}0.713 \\
(0.406)\end{array}$ & $\begin{array}{l}0.049 \\
(0.827)\end{array}$ & $\begin{array}{l}0.002 \\
(0.964)\end{array}$ & $\begin{array}{l}0.629 \\
(0.435)\end{array}$ & $\begin{array}{l}0.914 \\
(0.348)\end{array}$ & $\begin{array}{l}0.145 \\
(0.707)\end{array}$ & $\begin{array}{l}0.571 \\
(0.457)\end{array}$ & $\begin{array}{l}0.013 \\
(0.912)\end{array}$ & $\begin{array}{l}1.385 \\
(0.251)\end{array}$ & $\begin{array}{l}1.185 \\
(0.287)\end{array}$ \\
\hline \\
Heteroskedasticity
\end{tabular}

\begin{tabular}{|c|c|c|c|c|c|c|c|c|c|c|c|c|}
\hline - & GEXP & GREV & GDP & EXTR & $\mathrm{N} F \mathrm{R}$ & UEMR & GEXP & GREV & GDP & EXTR & NFR & UEMR \\
\hline C & $\begin{array}{l}27.765^{* * *} \\
(1.919)\end{array}$ & $\begin{array}{l}5.604^{* *} \\
*(0.631)\end{array}$ & $\begin{array}{l}18.662^{*} \\
* *(1.10 \\
1)\end{array}$ & $\begin{array}{l}57.825 \\
8 * *(5 . \\
77)\end{array}$ & $\begin{array}{l}9539.78 \\
8(6524 . \\
755)\end{array}$ & $\begin{array}{l}530.747 \\
* * *(53 . \\
653)\end{array}$ & $\begin{array}{l}55.977 * * \\
*(3.723)\end{array}$ & $\begin{array}{l}16.38^{* *} \\
*(2.181)\end{array}$ & $\begin{array}{l}24.046^{*} \\
* *(1.37 \\
3)\end{array}$ & $50.459(98.491)$ & $\begin{array}{l}4835.032^{* * *}(4 \\
23.801)\end{array}$ & $562.197 * * *(46.52)$ \\
\hline DLOG(GEXP) & & $\begin{array}{l}0.526 * * \\
*(0.082)\end{array}$ & $\begin{array}{l}0.048^{* *} \\
)^{*}(0.015 \\
\end{array}$ & & & $\begin{array}{l}0.891(0 . \\
566)\end{array}$ & & $\begin{array}{l}0.501^{* *} \\
*(0.107)\end{array}$ & & $-0.434(0.247)$ & & \\
\hline DLOG(OILP) & & $\begin{array}{l}0.405^{* *} \\
*(0.051)\end{array}$ & & & & & & & & & & \\
\hline OIID & & & & & & & $\begin{array}{l}0.066 * 8( \\
0.03)\end{array}$ & $\begin{array}{l}0.167 * * \\
*(0.037)\end{array}$ & $\begin{array}{l}0.004(0 . \\
008)\end{array}$ & $-0.375^{* * *}(0.074)$ & $-2.146(5.043)$ & $-0.779^{* * *}(0.254)$ \\
\hline DLOG(GDP) & & & & & & & $\begin{array}{l}0.872 *(0 . \\
422)\end{array}$ & & & $-3.644 * * *(0.88)$ & & \\
\hline DLOG(EXTR) & & & $\begin{array}{l}0.068^{8 *} \\
*(0.017 \\
)^{*}\end{array}$ & & & & & $\begin{array}{l}0.089(0 . \\
086)\end{array}$ & $\begin{array}{l}0.074^{* *} \\
{ }^{*}(0.023)\end{array}$ & & $19.263(12.747)$ & \\
\hline DLOG(EXCR) & & & & $\begin{array}{l}0.113( \\
0.087)\end{array}$ & & $\begin{array}{l}2.419 * * \\
*(0.589)\end{array}$ & & & & $0.243(0.185)$ & )$^{19.172 *(10.542}$ & \\
\hline DLOG(GREV) & & & & & $\begin{array}{l}53.383^{*} \\
8 *(6.26 \\
5)\end{array}$ & & & & & $0.464 *(0.235)$ & & $1.09 * *(0.414)$ \\
\hline @TREND & No & No & Yes & No & No & No & No & No & No & No & No & No \\
\hline CointEg(-1)* & $\begin{array}{l}0.621^{8 * *}( \\
0.043)\end{array}$ & $\begin{array}{l}0.446^{* *} \\
{ }^{*}(0.049)\end{array}$ & $\begin{array}{l}0.833^{8 *} \\
)^{8}(0.049\end{array}$ & $\begin{array}{l}0.173^{8} \\
8 *(0.0 \\
17)\end{array}$ & $\begin{array}{l}0.515 * * \\
{ }^{8}(0.058)\end{array}$ & $\begin{array}{l}0.895^{* *} \\
*(0.089)\end{array}$ & $\begin{array}{l}- \\
0.602^{* * *} \\
(0.04)\end{array}$ & $\begin{array}{l}0.26 * * * \\
(0.034)\end{array}$ & $\begin{array}{l}\overline{0} .806^{8 *} \\
8(0.06)\end{array}$ & $-0.598^{* * *}(0.134)$ & )$^{0.278^{8 * *}(0.024}$ & $-0.996 * * *(0.082)$ \\
\hline R-squared & 0.887 & 0.952 & 0.926 & 0.809 & 0.814 & 0.868 & 0.911 & 0.947 & 0.871 & 0.823 & 0.923 & 0.866 \\
\hline Adjusted R-squared & 0.883 & 0.946 & 0.913 & 0.793 & 0.807 & 0.852 & 0.895 & 0.935 & 0.861 & 0.745 & 0.904 & 0.849 \\
\hline F-statistic & $\begin{array}{l}204.117 \\
(0.000)\end{array}$ & $\begin{array}{l}160.087 \\
(0.000)\end{array}$ & $\begin{array}{l}71.868 \\
(0.000)\end{array}$ & $\begin{array}{l}52.822 \\
(0.000)\end{array}$ & & $\begin{array}{l}52.734 \\
(0.000)\end{array}$ & $\begin{array}{l}58.600 \\
(0.000)\end{array}$ & $\begin{array}{l}78.790 \\
(0.000)\end{array}$ & & & $50.219(0.000)$ & $51.482(0.000)$ \\
\hline
\end{tabular}

\section{References}

Ademola, et. al., 2015. Government Expenditure, Oil Revenue and Economic Growth in Nigeria. International Journal of Economics, Commerce and Management United Kingdom. III (5): pp.180-202. 
Adesola, O.A., Adesodun, A.I. and Adekola, D.R. (2014) 'Impact of oil Revenue on Economic Development in Nigeria (1981-2012)', Journal of Social and Development Sciences, 5(2), pp. 73-78.

Aladejare, S. A. 2014. Government spending and economic growth: evidence from Nigeria. Available from: https://mpra.ub.uni uenchen.de/43916/. (Accessed 23rd August, 2020).

Ali, M.A., Saifullah, M.K. and Kari, F.B. (2015) 'The Impact of key Macroeconomic factors on Economic Growth of Bangladesh: A VAR Coo-integration Analysis.', International Journal of Management Excellence, 6(1), pp. 668-673.

Aliyan, A.M. (2013) 'Effect of oil prices fluctuations on industrial productions in Iran.' European Online Journal of Natural and Social Sciences, 2(4), pp. 572-583.

Al-Qahtani, A., Balistreri, E. and Dahl, C. (2008) Literature Review on Oil Market Modelling and OPEC'S Behaviour. Division of Economics and Business, Colorado School of Mines, Golden Col. 80401. Available at: http://dahl.mines.edu/LitReviewOPEC.pdf (Accessed: 23 April 2021).

Al-Qudsi, S. and Ali, M. (2016) Economic Growth Implications of Oil Price Fluctuations: The GCC Context. Available at: https://www.dohainstitute.edu.qa/MEEA2016/Downloads/Sulayman\%20AlQudsi.pdf (Accessed: 17 July 2020).

Al-Yousef, N. (1998) Economic Models of OPEC behaviour and the role of Saudi Arabia. Availableat: https://www.surrey.ac.uk/economics/files/apaperspdf/SEED\%2094.pdf (Accessed: 23 April 2020).

Al-Zeaud, H. A. 2015. The Causal Relationship between Government Revenue and Expenditure in Jordan. International Journal of Management and Business Research. 5(2): pp.117-127.

Antwi, S., Mills, E. F. E. A. and Zhao, X. (2013) 'Impact of Macroeconomic Factors on Economic Growth in Ghana: A Cointegration Analysis.' International Journal of Academic Research in Accounting, Finance and Management Sciences, 3(1), pp. 35-45.

Arewa, A. and Nwakahma, C. (2013) 'Macroeconomic variables and the dynamic effect of public expenditure: Long-term trend analysis in Nigeria.' Journal of Knowledge Management, Economics and Information Technology, 3(6), pp. 1-32.

Ayadi, O. F. 2005. Oil price fluctuations and the Nigerian economy. OPEC Energy Review. 29(3): pp.199-217.

Aydın, L. and Acar, M. (2011) 'Economic impact of oil price shocks on the Turkish economy in the coming decades: A dynamic CGE Analysis, Energy Policy, 39(3), pp. 1722-1731. doi: 10.1016/j.enpol.2010.12.051.

Balke, N.S., Brown, S.P.A. and Yücel, M.K. (2002) 'Oil Price Shocks and the U.S. Economy: Where Does the Asymmetry Originate?', The Energy Journal, 23(3), pp. 27-52. doi: 10.5547/ISSN0195-6574-EJ-Vol23-No32 .

Balli, E., Tras, M.F. and Sigeze, C. (2016) 'Impact of oil price on turkish macroeconomic variables.', Journal of Economic and Social Development, 3(2), pp. 51-58.

Barkhordar, Z. A. and Saboohi, Y. 2013. Assessing alternative options for allocating oil revenue in Iran. Energy Policy. 63(1): pp.1207-1216.

Baumeister, C. and Kilian, L. (2016) 'Forty Years of Oil Price Fluctuations: Why the Price of Oil May Still Surprise Us', The Journal of Economic Perspectives, 30(1), pp. 139-160 doi: 10.1257/jep.30.1.139.

Benton, T. and Craib, I. (2001). Philosophy of Social Science: The Philosophical Foundations of Social Thought. SAGE Journals. 27(1): pp.184-186 https://doi.org/10.1177/030981680307900115.

Berry, W.D. (1990) 'The Confusing Case of Budgetary Incrementalism: Too Many Meanings for a Single Concept.' Journal of Politics, 52(1), pp. 167-196.

Blanchard, O.J. and Gali, J. (2007) The Macroeconomic Effects of Oil Price Shocks: Why are the 2000s, so Different from the 1970s. Available at: : http://www.nber.org/chapters/c0517 (Accessed: 14 July 2020).

Bohi, D. R. 1991. On the macroeconomic effects of energy price shocks. Resources and Energy. 13(2): pp.145162.

Bollino, C.A. (2007) 'Oil prices and the U.S. trade deficit.', Journal of Policy Modelling, 1(29), pp. 729-738. doi: https://doi.org/10.1016/j.jpolmod.2007.06.009.

Brock, J. (2015). Angola Economy set to Slow as oil prices collapse. Available at: https://www.reuters.com/article/angola-economy-idUSL6N0V645F20150129 (Accessed: 6 May 2021).

Brown, S.P. and Yucel, M.K. (2002) 'Energy prices and aggregate economic activity: An interpretative survey.' The Quarterly Review of Economics and Finance, 42(2), pp. 193-208.

Bruno, M. and Sachs, J. (1986) 'Economics of Worldwide Stagflation. Cambridge, Mass.', Harvard University Press.

Bryman, A. (2008). Social Research Methods. $3^{\text {rd }}$ ed. New York: Oxford University press.

Bryman, A. (2016) Social Research Methods. 5th Edition ed. Italy: Oxford University Press.

Bryman, A. and Bell, E. (2007). The Ethics of Management Research: An Exploratory Content Analysis. British Journal of Management. 18(1): pp.63-77.

Bryman, A. and Bell, E. (2015). Business research methods. 4th ed. US Higher Education, Oxford University 
Press.

Buchanan, J. M. and Wagner, R. W. (1978). Dialogues concerning fiscal religion. Journal of Monetary Economics. 4(3): pp.627-636.

Caiden, N. (1994) 'Budgeting in Historical and Comparative Perspective.' Public Budgeting and Finance, 14(1), pp. 44-57.

Cesaratto, S. (2008) Endogenous growth theory twenty years after: A critical assessment. Available at: http://www.boeckler.de/pdf/v_2008_10_31_cesaratto.pdf (Accessed: 13 December 2020).

Cibulka, J. G. 1987. Theories of Education Budgeting: Lessons from the Management of Decline. SAGE Journals. https://doi.org/10.1177/0013161X87023001003 . SAGE Journals. 23(1): pp.7-40.

Collis, J. and Hussey, R. (2009) Business Research: A Practical Guide for Undergraduate and Postgraduate Students. Third ed. UK: Palgrave Macmillan.

Collis, J. and Hussey, R. (2014) Business Research: A Practical Guide for Undergraduate and Postgraduate students. Fourth ed. UK: Palgrave Macmillan.

Coolican, H. 2014. Research methods and statistics in psychology. 6th ed. New York, NY, US: Psychology Press.

Corbin, J. and Strauss, A. (2008). Basics of qualitative research: Techniques and procedures for developing grounded theory. http://dx.doi.org/10.4135/9781452230153. 3rd ed. Sage Publications, Inc.

Creswell, J. 2014. Research method: Qualitative, quantitative and mixed method approaches. 4th ed. Sage Publication, Inc.

Cunado, J. and De Gracia, F.P. (2005) 'Oil prices, economic activity and inflation: evidence for some Asian countries', The Quarterly Review of Economics and Finance, 45(1), pp. 65-83.

Darby, M.R. (1982) 'The price of oil and world inflation and recessions.', American Economic Review, 72, pp. $738-751$

Davis, O.A., Dempster, M.A. and Wildavsky, A. (1966) 'A Theory of the Budgetary Process.', American Political Science Association, 60(3), pp. 529-547.

Downs, G.W. and Rocke, D.M. (1984) 'Theories of Budgetary Decision-making and Revenue Decline.', Policy Sciences - Elsevier, 16(4), pp. 329-347.

Eastrby-Smith, M., Thorpe, R. and Jackson, P. (2012) Management Research. 4th edn. London: SAGE Publications Inc.

Elgouacemi, A. et al. (2020), The fiscal implications of the low-carbon transition. Available at: https://doi.org/10.1787/6cea13aa-en. (Accessed on the 7 May 2021)

Eltony, N. and Al-Awadi, M. (2001) 'Oil price fluctuations and their impact on the macroeconomic variables of Kuwait: A case study using a VAR model.', International Journal of Energy Research, 25(11), pp. 939-95 doi: https://doi.org/10.1002/er.731.

Energy Information Administration (2017). Country Analysis Brief: Angola. Washington, DC: Energy Information Administration.

Engebretsen, R. (2015) Angola: How long can Angola hold on with low oil prices? Available at: http://allafrica.com/stories/201512281905.html (Accessed: 22 March 2021).

Farzanegan, M.R. and Markwardt, G. (2009) 'The effects of oil price shocks on the Iranian economy', Energy Economics, 31(1), pp. 134-151. doi: 10.1016/j.eneco.2008.09.003.

Friedman, M. 1978. The Limitations of Tax Limitation. Policy Review: pp.7-14.

Galliers, R. D. (1991). Choosing appropriate information systems research approaches: a revised taxonomy. Available from: http://citeseerx.ist.psu.edu/viewdoc/summary?doi=10.1.1.471.143 (Accessed 4th July 2020).

Gliner, J. A., Morgan, G. A. and Leech, N. L. (2009). Research methods in applied settings: An integrated approach to design and analysis. 2nd ed. Routledge/Taylor \& Francis Group.

Gosling, J.J. (2016) Budgetary Politics in American Governments. First Edition edn. New York and London: Routledge Taylor and Francis Group.

Gounder, R. and Bartleet, M. (2007) Oil Price Shocks and Economic Growth: Evidence for New Zealand. Available at: https://editorialexpress.com/cgibin/conference/download.cgi?db_name=NZAE2007\&paper_id=108 (Accessed: 16 July 2020).

Grossman, G.M. and Helpman, E. (1994) 'Endogenous Innovation in the Theory of Growth.', The Journal of Economic Perspectives, 8(1), pp. 23-44.

Gulati, P. M. (2009). Research management: Fundamental and applied research. 2nd Revised ed. Global India Publications.

Hamdi, H. and Sbia, R. (2013) 'Dynamic relationships between oil revenues, government spending and economic growth in an oil-dependent economy',Economic Modelling, 35, pp. 118-125. doi: 10.1016/j.econmod.2013.06.043.

Hamilton, J. D. and Flavin, M. A. (1986). 'On the Limitations of Government Borrowing: A Framework for 
Empirical Testing'. National Bureau of Economic Research. Available at: https://www.nber.org/system/files/working_papers/w1632/w1632.pdf (Accessed: 14 May 2021).

Hamilton, J.D. (1983) 'Oil and the Macroeconomy since World War II', Journal of Political Economy, 91(2), pp. 228-248. doi: 10.1086/261140.

Hamilton, J.D. (2005) 'Oil and the Macroeconomy', The New Palgrave Dictionary of Economics Palgrave Macmillan, London. Available online at http://www.dictionaryofeconomics.com/dictionary.JiménezRodríguez, Rebeca and Marcelo Sánchez. pp. 201-228.

Hamilton, J.D. (2009a) "'Understanding Crude Oil Prices". The Energy Journal, International Association for Energy Economics.', The Energy Journal, 30(2), pp. 179-206. doi: 10.5547/ISSN0195-6574-EJ-Vol30-No29.

Hamilton, J.D. (2009b) Causes and Consequences of the Oil Shock of 2007-08. Available at: http://www.brookings.edu/about/projects/bpea/editions/ /media/Projects/BPEA/Spring\%202009/2009a bpea hamilton.PDF (Accessed: 15 January 2021).

Hayes, A. (2015) Falling oil prices could bankrupt these countries. Available at: http://www.investopedia.com/articles/active-trading/020215/falling-oil-prices-could-bankrupt-thesecountries.asp (Accessed: 23 November 2020).

Hesary, F. T. (2013). An Estimation of the Impact of Oil Shocks on Crude Oil Exporting Economies and Their Trade Partners. Frontiers of Economics in China. 8(4): pp.571-591.

Hesary, F.T., Yoshino, N., Abdoli, G. and Farzinvash, A. (2013) 'An Estimation of the Impact of Oil Shocks on Crude Oil Exporting Economies and Their Trade Partners', Frontiers of Economics in China, 8(4), pp. 571591. doi: 10.3868/s060-002-013-0029-3.

Hooker, M. A. (1996). What happened to the oil price macro-economy relationship? Journal of Monetary Economics. 38(2): pp.195-213.

Hooker, M.A. (1999) Are oil shocks inflationary? Asymmetric and nonlinear specifications versus changes in regime. Available at: https://www.federalreserve.gov/pubs/feds/1999/199965/199965pap.pdf (Accessed: 14 July 2020).

Hoover, K.D. and Perez, S.J. (1994) 'Post Hoc Ergo Propter Hoc Once More: An Evaluation of "Does Monetary Policy Matter? in the Spirit of James Tobin,"', Journal of Monetary Economics, (34), pp. 47-73.

Ibrahim, M.M. and Proctor, R.A. (1992) '"Incremental Budgeting in Local Authorities"', International Journal of Public Sector Management, 5(5), pp. 11-27.

Idrisov, G., Kazakova, M. and Polbin, A. 2015. "Theoretical Interpretation of the Oil Prices Impact on Economic Growth in Contemporary Russia." Russian Journal of Economics. 3(1): pp.257-272.

International Energy Agency. (2017), World Energy Statistics. Paris: International Energy Agency. Available at: https://www.eia.gov/outlooks/ieo/pdf/0484(2017).pdf. (Accessed: 12 May 2021).

Iwayemi A. and Fowowe, B. (2011). Impact of Oil Price Shocks on Selected Macroeconomic variables in Nigeria. Energy Policy. 39(2): pp.603-612.

Jarque, C. M. and Bera, A. K. (1982). A Test for Normality of Observations and Regression Residuals. DOI: 10.2307/1403192. International Statistical Review. 55(2): pp.163-172.

Jbir, R., and Zouari-Ghorbel, S. 2009. Recent oil price shocks and Tunisian economy. Energy Policy. 37(3): pp.1041-1051 https://doi.org/10.1016/j.enpol.2008.10.044.

Jones, D. W., Leiby, P. N. and Paik, I. K. (2004). "Oil price shocks and the macroeconomy: What has been learned since 1996." Energy Journal. 25(1): pp.1-33.

Jordan, M.M. (2002) 'Punctuatd Equilibrium: An Agenda Based Theory of Budgeting.', in Khan, A. and Hildreth, W.B. (eds.) Budget Theory in the Public Sector. First edn. London: Quorum Books: Westport, Connecticut, pp. 202-215

Kaplan, F. (2015). Oil Price, Exhange Rate and Economic Growth in Russia: A Multiple Structural Break Approach. Advances in Management and Applied Economics. 5(4): pp.91.

Khan, A. and Hildreth, W.B. (eds) (2002) Budget theory in the public sector. 1st Ed. London: Westport, Connecticut; Series number.

Kryeziu, A. (2016) 'The Impact of Macroeconomic Factors in Economic Growth.', European Scientific Journal, 12(7), pp. 331-345.

Lahn G. and Bradley, S. (2020). OECD Development Matters: How COVID-19 is Changing the Opportunities for Oil and Gas-Led Growth. Available at: https://oecd-development-matters.org/2020/07/10/how-covid-19-ischanging-the-opportunities-for-oil-and-gas-led-growth/ (Accessed: 14 May 2021).

Lardic, S. and Mignon, V. (2008) 'Oil prices and economic activity: An asymmetric cointegration approach.', Energy Economics, 30(3), pp. 847-855.

Lee, K., Ni, S. and Ratti, R. A. (1995). "Oil Shocks and the Macroeconomy: The Role of Price Variability,”. The Energy Journal. 16(4): pp.39-56. doi.org/10.5547/ISSN0195-6574-EJ-Vol16-No4-2

Likert, R. (1932). A Technique for the Measurement of Attitudes. Available 
from: https://legacy.voteview.com/pdf/Likert 1932.pdf (Accessed 7th March 2020).

Lindblom, C. E. (1958). Tinbergen on policy-making. The Journal of Political Economy. The Journal of Political Economy. 66(6): pp.531-538.

Lindblom, C. E. (1959). The Science of "Muddling Through". Public Administration Review. 19(2): pp.79-88.

Lindblom, C. E. (1987). Alternatives to Validity: Some Thoughts Suggested by Campbell s Guidelines. SAGES Journals. 8(3): pp.509-520.

Linderoth, H. (1992) 'Target revenue theory and Saudi Arabian oil policy.', Energy Policy, 20(11), pp. 1078-1088. doi: https://doi.org/10.1016/0301-4215(92)90166-Y.

Lorusso, M. and Pieroni, L. (2015) Causes and Consequences of Oil Price Shocks on the UK Economy. Centre for Energy Economics Research and Policy (CEERP). Available at: http://ceerp.hw.ac.uk/RePEc/hwc/wpaper/002.pdf (Accessed: 15 July 2020).

Lowery, D. and Berry W. D. (1983). The Growth of Government in the United States: An Empirical Assessment of Competing Explanations. American Journal of Political Science. 27(4): pp.665-694.

Malik, A. (2010). Oil Prices and Economic Activity in Pakistan. South Asia Economic Journal. 11(2): pp.223-244 DOI: $10.1177 / 139156141001100204$.

Marques, A.C., Fuinhas, J.A. and Menegaki, A.N. (2016) 'Renewable vs non-renewable electricity and the industrial production nexus: Evidence from and ARDL bounds test approach for Greece.', Renewable Energy, 96, pp. 645-655.

Mellor, D.J. and Moore, K. A. 2014. The use of Likert scales with children. Journal of Pediatric Psychology. 39(3): pp.369-379 DOI:10.1093/jpepsy/jst079.

Mohammed, M. (2018). 'Oil Production and Economic Growth in Angola'. International Journal of Energy Economics and Policy, 2018, 8(2), 127-131.

Monaldi, F. (2015). The Impact of the Decline in Oil Prices on the Economics, Politics and Oil Industry of Venezuela.

Available from: https://energypolicy.columbia.edu/sites/default/files/Impact\%20of\%20the\%20Decline $\% 20 \mathrm{in} \% 20 \mathrm{Oil}$ \%20Prices\%20on\%20Venezuela_September\%202015.pdf (Accessed 9th June 2020).

Mork, K.A. (1989) 'Oil and the Macroeconomy When Prices Go Up and Down: An Extension of Hamilton's Results', Journal of Political Economy, 97(3), pp. 740-744. doi: 10.1086/261625.

Morse, J.M. and Niehaus, L. (2009) Mixed Method Design: Principles and Procedures. First Ed. USA: Left Coast Press, Inc.

Mory, J.F. (1993) 'Oil Price and Economic Activity: Is the Relationship Symmetric?', The Energy Journal, 4, pp. $151-162$

Mupimpila, C. H., Inale, L. E. D., and Offat, B. O. M. (2015). The causality between government revenue and expenditures in Botswana. International Journal of Economic. 8(1): pp.1-14.

Narayan, P.K. and Smyth, R. (2005) 'The Residential Demand for Electricity in Australia: An Application of the Bounds Testing Approach to Cointegration.', Energy Policy, 33, pp. 467-474.

Nicholson, W. and Snyder, C. (2007) Microeconomic Theory: Basic Principles and Extensions. $10^{\text {th }}$ Ed. Thomson Higher Education. United States of America

Nkoro, E. and Uko, A.K. (2016) 'Autoregressive Distributed Lag (ARDL) Cointegration Technique: Application and Interpretation', Journal of Statistical and Econometric Methods, 5(4), pp. 63-91.

Nzimande, N.P. and Msomis, S. (2016) Oil Price Shocks and Economic Activity: The Asymmetric Cointegration Approach in South Africa. Available at: http://saef.ukzn.ac.za/Libraries/Working_Paper/SAEF_Oil_Price_Shocks-NN_SM.sflb.ashx (Accessed: 16 July 2020).

Ocholla, D.N. and Le Roux, J. (2011) Conception and Misconceptions of Theoretical Frameworks in Library and Information Science Research. Available at: http://www.lis.uzulu.ac.za/2011/Ocholla\%20and\%20Le\%20Roux\%20prolissa\%20conference\%202011 \%20revised\%2016\%20March\%202011.pdf(Accessed: 9th December 2020).

OECD (2020) Oil Price Developments: Drivers, Economic Consequences and Policy Responses. Available at: oecd.org/economy/outlook/34080955.pdf (Accessed: 17 March 2021).

OECD (2020). 'The Impact of Coronavirus (COVID-19) and the Global Oil Price Shock on the Fiscal Position of Oil-Exporting Development Countries'. Available at: https:/www.oecd.org/coronavirus/policyresponses/the-impact-of-coronavirus-covid-19-and-the-global-oil-price-shock-on-the-fiscal-position-of-oilexporting-developing-countries-8bafbd95/ (Accessed: 14 March 2021).

Ogundipe, O.M., Ojeaga, P. and Ogundipe, A.A. (2014) 'Oil Price and Exchange Rate Volatility in Nigeria', Journal of Economics and Finance (IOSR), 5(4), pp. 1-9

Oladosu, G. (2009) 'Identifying the oil price-macroeconomy relationship: An empirical mode decomposition analysis of US data.', Energy Policy., 37(12), pp. 5417-5426.

Olaoye, F.O. (2014) 'An exploratory evaluation of legislative lawlessness in the Nigerian budget 
process.', Singaporean Journal of Business, Economics and Management Studies, 3(2), pp. 39-47.

Olomola, P.A. and Adejumo, A.V. (2006). Oil price shock and macroeconomic activities in Nigeria. International Research Journal of Finance and Economics. 3(1): pp.28-34.

Oriakhi, D. E. and Iyoha, O. D. (2013). Oil Price Volatility and its Consequences on the Growth of the Nigerian Economy: An Examination (1970-2010). Asian Economic and Financial Review. 3(5): pp.683-702.

Ouliaris, S., Pagan, A. R. and Restrepo, J. (2018). Quantitative Macroeconomic Modelling with Structural Vector Autoregressions - $\quad$ An EViews Implementation. Available from: https://www.eviews.com/StructVAR/structvar.html (Accessed 13 April 2020).

Ozlanlea, U. and Pekkurnaz, D. (2010) 'Oil prices and current account: A structural analysis for the Turkish economy.', Energy Policy Volume, 38(8), pp. 4489-4496. doi: https://doi.org/10.1016/j.enpol.2010.03.082.

Padgett, J.F. (1980) 'Rounded Rationality in Budgetary Research.', American Political Science Association, 74(2), pp. 354-372.

Parker, J. (2012) 5 Theories of $\quad$ Endogenous $\quad$ Growth. Available at: http://www.reed.edu/economics/parker/s12/314/Coursebook/Ch_05.pdf (Accessed: 14 December 2020).

Peacock, A. T. and Wiseman, J. (1979) 'Approaches to the Analysis of Government Expenditure Growth.', SAGE Journals: Public Finance Quarterly, 7(1), pp. 3-23. doi: https://doi.org/10.1177/109114217900700101.

Pesaran, M.H., Shin, Y. and Smith, R.J. (2001) 'Bounds testing approaches to the analysis of level relationships.', Journal of Applied Econometrics, 16(2001), pp. 289-326.

Petroff, A. and Yellin, T. (2015) What it Costs to Produce Oil. Available at: http://money.cnn.com/interactive/economy/the-cost-to-produce-a-barrel-ofoil/index.html?sr=twCNN112515the-cost-to-produce-a-barrel-ofoil0402AMStoryPhoto\&linkId=19035175 (Accessed: 20 July 2020).

Reddick, C.G. (2004a) Rational Expectations Theory and Macro Budgetary Decision-Making: Comparative Analysis of Canada, UK and USA. Available at: http://pracademics.com/attachments/article/624/Ar1\%20Reddick.pdf (Accessed: 5th December 2020).

Reddick, C.G. (2004b) 'Rational Expectations Theory and Macro Budgetary Decision-Making: Comparative Analysis of Canada, UK and USA.', Journal of Public Budgeting, Accounting and Financial Management, 16(3), pp. 316-356.

Romer, C. D. and Romer, D. H. (1989). Does Monetary Policy Matter? A New Test in the Spirit of Friedman and Schwartz. National Bureau of Economic Research, Inc. 4(1): pp.121-184.

Romer, P.M. (1990) 'Endogenous Technological Change.', Journal of Political Economy, 98(5), pp. 71-102.

Romer, P.M. (1994) 'The Origins of Endogenous Growth', Journal of Economic perspectives, 8(1), pp. 3-22.

Saunders, M., Lewis, P. and Thornhill, A. (2012) Research Methods for Business Students. 6th Ed. England: Pearson Education Limited.

Sharkansky, I. 1969. Agency Requests, Gubernatorial Support, and Budget Success in State Legislatures.". American Political Science Review. 1(62): pp.1220-1231.

Shi, X. and Sun, S. (2012) Oil Price Shock and Macroeconomy in China and India: Insights from the Energy Sector. Available at: file://C:/Users/1404750/Downloads/Shi2012abstract\%20(1).pdf(Accessed: 15 July 2020).

Sielke, C. C. (1995). Budgetary decision making: Is it rational, incremental or garbage can? American Association of School Administrators Annual Report, New Orleans, LA. Available from: http://eric.ed.gov/?id=ED383048 (Accessed 5th April 2021).

Simon, M.K. and Goes, J. (2013)Developing a Theoretical Framework. Available at: https://drannejonesuas.files.wordpress.com/2013/10/recipe-for-a-theoretical-framework.pdf (Accessed: 9th December 2020).

Sinha, R. (2015) What are the differences between the Solow Growth Model and the Endogenous Growth Model? Available at: https:/www.quora.com/What-are-the-differences-between-the-Solow-Growth-Modeland-the-Endogenous-Growth-Model (Accessed: 14th December 2020).

Solo, R. 1970. Growth M. Theory: An Exposition. Available from: https://EconPapers.repec.org/RePEc:oxp:obooks:9780195109030 (Accessed 18th July 2020).

Stober, E. O. (2016). Crude Oil, Exchange Rate and the Convergence of Foreign Reserves: A VECM of Nigeria's Monetary Policy Tools. International Journal of Advances in Management and Economics. 5(2): pp.127-133.

Suliman, M. and Osman, O.A. (1994) War in Darfur: The desert versus the oasis syndrome. Institute for African Alternatives, London, UK. Available at: http://new.ifaanet.org/?p=462 (Accessed: 5th May 2021).

Swanson, R.A. and Chermack, T.J. (2013) Theory Building in Applied Disciplines. First Edition edn. United States: Berrett-Koehler Publishers.

Taghizadeh-Hesary, F. (2020) Economic impacts of the COVID-19 pandemic and oil price collapse. Available at: https://www.asiapathways-adbi.org/2020/05/economic-impacts-covid-19-pandemic-and-oil-pricecollapse/ (Accessed: 17th March 2021). 
Taghizadeh-Hesary, F. and Yoshino, N. (2015) Macroeconomic Effects of Oil Price Fluctuations on Emerging and Developed Economies in a Model Incorporating Monetary Variables. Available at: https://www.econstor.eu/bitstream/10419/145394/1/838107419.pdf (Accessed: 7th January 2021).

Tatom, J. (1987) 'The macroeconomic effects of the recent fall in oil', Federal Reserve Bank of St. Louis Review, (Jun), pp. 34-45.

Thompson, J. A. (1987). “Agency Requests, Gubernatorial Support, and Budget Success in State Legislatures Revisited,'. The Journal of Politics. 49(3): pp.756-779.

Todaro, M.P. and Smith, S.C. (2004) Economic Development. 8th Ed. India: Person Education Ltd.

Trading Economics (2016) Crude Oil 1946-2016. Available at: http://www.tradingeconomics.com/commodity/crude-oil (Accessed: 7 April 2021).

Trochim, W.M. (2006) Research Methods Knowledge Based. Available at: http://www.socialresearchmethods.net/kb/design.php (Accessed: 9th December 2020).

Waite, M. and Hawker, S. (2009). Oxford paperback dictionary and thesaurus. 3rd ed. London: Macmillan.

Weil, D.N. (2016) Economic Growth: International Edition. 3rd edn. USA: Routledge

Whicker, M. L. and Mo, C. (2002). The impact of agency mission on agency budget strategy: A deductive theory. In: A. Khan and W. B. Hildreth. eds. Budget theory in the public sector. First ed. London: Quorum Books: Westport, Connecticut. 2002, pp.216-245.

Wildavsky, A. (1964). The Politics of the Budgetary Process, Boston, MA: Little, Brown, and Co. (Revised in 1974, 1979 and 1984). Available from: https:/www.scirp.org/(S(351jmbntvnsjtlaadkposzje))/reference/ReferencesPapers.aspx?ReferenceID $=1247092$ (Accessed 5th June 2020).

Wilson, L.A. and Sylvia, R. (1993) 'Changing Revenue Conditions and State Budgetary Decisions.', Journal of Public Administration Research and Theory, 3(3), pp. 319-333.

World Bank. (2017), World Bank World Development Indicators. Washington, DC: World Bank.

Yoshino, N. and Taghizadeh-Hesary, F. (2014) 'Economic impacts of oil price fluctuations in developed and emerging economies', IEEJ Energy Journal, 9(3), pp. 58-75.

Zhang, D. (2008) 'Oil Shock and economic growth in Japan: A nonlinear approach.', Energy Economics, 30(5), pp. 2374-2390.

Zielder, D.L. (2007) What is Theoretical Framework? University of South Florida. Available at: http://www.coedu.usf.edu/jwhite/secedseminar/theoryframe.pdf (Accessed: 9th December 2020). 